\title{
Afferent neuronal control of type-I gonadotropin releasing hormone neurons in the human
}

\section{Erik Hrabovszky ${ }^{1}{ }^{*}$ and Zsolt Liposits ${ }^{1,2}$}

1 Laboratory of Endocrine Neurobiology, Institute of Experimental Medicine, Hungarian Academy of Sciences, Budapest, Hungary

${ }^{2}$ Department of Neuroscience, Faculty of Information Technology, Pázmány Péter Catholic University, Budapest, Hungary

\section{Edited by:}

Susan Wray, National Institutes of Health, USA

\section{Reviewed by:}

Taisen Iguchi, National Institute for Basic Biology, Japan

Anna Petryk, University of Minnesota, USA

\section{*Correspondence:}

Erik Hrabovszky, Laboratory of Endocrine Neurobiology, Institute of Experimental Medicine, Hungarian Academy of Sciences, 43 Szigony Street, Budapest 1083, Hungary e-mail:hrabovszky.erik@koki.hu
Understanding the regulation of the human menstrual cycle represents an important ultimate challenge of reproductive neuroendocrine research. However, direct translation of information from laboratory animal experiments to the human is often complicated by strikingly different and unique reproductive strategies and central regulatory mechanisms that can be present in even closely related animal species. In all mammals studied so far, type-I gonadotropin releasing hormone $(\mathrm{GnRH})$ synthesizing neurons form the final common output way from the hypothalamus in the neuroendocrine control of the adenohypophysis. Under various physiological and pathological conditions, hormonal and metabolic signals either regulate $\mathrm{GnRH}$ neurons directly or act on upstream neuronal circuitries to influence the pattern of pulsatile GnRH secretion into the hypophysial portal circulation. Neuronal afferents to $\mathrm{GnRH}$ cells convey important metabolic-, stress-, sex steroid-, lactational-, and circadian signals to the reproductive axis, among other effects. This article gives an overview of the available neuroanatomical literature that described the afferent regulation of human $\mathrm{GnRH}$ neurons by peptidergic, monoaminergic, and amino acidergic neuronal systems. Recent studies of human genetics provided evidence that central peptidergic signaling by kisspeptins and neurokinin B (NKB) play particularly important roles in puberty onset and later, in the sex steroid-dependent feedback regulation of $\mathrm{GnRH}$ neurons. This review article places special emphasis on the topographic distribution, sexual dimorphism, aging-dependent neuroanatomical changes, and plastic connectivity to $\mathrm{GnRH}$ neurons of the critically important human hypothalamic kisspeptin and NKB systems.

Keywords: GnRH neurons, LHRH, kisspeptin, afferent, humans, hypothalamus, infundibular nucleus, reproduction

\section{INTRODUCTION}

In all mammals, type-I gonadotropin releasing hormone (GnRH) synthesizing neurons form the final common output way from the hypothalamus in the neuroendocrine control of reproduction. The pulsatile release of GnRH into the hypophysial portal circulation $(1,2)$ drives the synthesis and secretion of follicle stimulating hormone (FSH) and luteinizing hormone (LH) from anterior pituitary gonadotrophs (3). Circulating FSH and LH, in turn, stimulate gametogenesis and the synthesis and secretion of the gonadal steroid hormones, testosterone from the testes and $17 \beta$-estradiol

Abbreviations: ARC, arcuate nucleus; $\mathrm{CRH}$, Corticotropin-releasing hormone; E2, $17 \beta$-estradiol; $\mathrm{ER} \alpha, \alpha$ estrogen receptor isoform; $\mathrm{ER} \beta, \beta$ estrogen receptor isoform; $\mathrm{FSH}$, follicle stimulating hormone; GABA, $\gamma$-aminobutyric acid; $\mathrm{GABA}_{\mathrm{A}} / \mathrm{GABA}_{B}$, Type A, B GABA receptor; Gal-R1, type-I galanin receptor; GFP, green fluorescent protein; $\mathrm{GnIH}$, gonadotropin-inhibiting hormone; $\mathrm{GnRH}$, type-I gonadotropinreleasing hormone; GPR147, RFRP(GnIH) receptor; Inf, infundibular nucleus; InfS, infundibular stalk; IR, immunoreactive; KA2, kainate receptor-2; KCC2, $\mathrm{K}-\mathrm{Cl}$ co-transporter; KISS1R, kisspeptin receptor; KNDy, kisspeptin/neurokinin B/dynorphin; KP, kisspeptin; LH, luteinizing hormone; mRNA, messenger ribonucleic acid; NK1-3, neurokinin receptor, type 1-3; NKB, neurokinin B; NPY, neuropeptide $Y$; NR1, $N$-methyl-D-aspartate receptor-1; OVLT, organum vasculosum of the lamina terminalis; RFRP, RF-amide related peptide; RP3V, rostral periventricular area of the third ventricle; RT-PCR, reverse transcription-polymerase chain reaction; SP, Substance P; VGLUT1/VGLUT2, Type-1/Type-2 vesicular glutamate transporter; VIAAT, vesicular inhibitory amino acid transporter; Y5, Type 5 NPY receptor.
(E2) and progesterone from the ovaries. Under various physiological and pathological conditions, hormonal and metabolic signals regulate GnRH neurons directly and also act on upstream neuronal circuitries to influence the pattern of episodic GnRH secretion. Neuronal afferents to GnRH cells convey important metabolic-, stress-, sex steroid-, lactational-, circadian, and other signals to the reproductive axis. Our knowledge about these inputs is based primarily on the results of physiological and anatomical studies of laboratory species, in particular, rodents. Although it is tempting to assume that the most critical central mechanisms of reproduction are evolutionarily conserved, the direct extrapolation from the results of animal experiments would overlook many obvious species differences already revealed in the hypothalamic regulation of reproduction.

In this article we give an overview of the relatively few neuroanatomical reports that described the afferent regulation of human GnRH neurons by peptidergic, monoaminergic, and amino acidergic neuronal systems. The physiological interpretation of these human neuroanatomical results will be given in the light of experimental data from laboratory species. A special emphasis of the review will be placed on recent data about central kisspeptin (KP) and neurokinin B (NKB) signaling to GnRH neurons. Human genetics provide evidence that central peptidergic signaling by these two neuropeptides play particularly important 
roles in puberty onset and later, in the sex steroid-dependent feedback regulation of GnRH neurons. We will address the topographic distribution, sexual dimorphism, aging-dependent neuroanatomical changes, and plastic connectivity to GnRH neurons of the human hypothalamic KP and NKB systems. Finally, some critically important remaining questions will be addressed.

\section{ANATOMY OF HUMAN GnRH NEURONS ORIGIN AND TOPOGRAPHIC DISTRIBUTION: IMMUNOHISTOCHEMICAL AND IN SITU HYBRIDIZATION RESULTS}

In mammals, GnRH neurons originate in the olfactory placode and migrate prenatally into the forebrain along the olfactoryvomeronasal nerves $(4,5)$. In humans, this migratory process is impaired in patients with Kallmann syndrome (6), characterized by hypogonodotropic hypogonadism and anosmia. Species differ significantly regarding the final distribution of $\mathrm{GnRH}$ neurons. While the location of GnRH neurons in the most extensively studied laboratory rats and mice is confined to the septal-preoptic region $(7,8)$, other species including the sheep (9), the guinea pig (10), the ferret (11), the bat (11), or the monkey (11) also have a distinct GnRH cell populations more caudally in the mediobasal hypothalamus/arcuate nucleus (ARC). In addition to a relatively loose distribution of the GnRH cell bodies which quite often lie outside the anatomical borders of classical hypothalamic nuclei, the anatomical definition of the human GnRH neuronal system is complicated somewhat further by the use of different nomenclature in various anatomical reports using in situ hybridization (12) and immunohistochemistry $(11,13-25)$. Based on combined results of these studies, the majority of $\mathrm{GnRH}$ neurons in the human are located within a $2 \mathrm{~mm}$ wide periventricular zone and show decreasing numbers in the mediolateral direction. Labeled somata are scattered within the septal region, the diagonal band of Broca, the preoptic region, the periventricular hypothalamic nucleus, the mediobasal hypothalamus (infundibular nucleus, Inf and infundibular stalk, InfS), the nervus terminalis, and olfactory regions. In situ hybridization studies revealed an additional neuron population expressing intermediate levels of the $\mathrm{GnRH}$ transcript (12). These neurons (termed type-III GnRH neurons) exhibit very large perikarya (>500 $\mu \mathrm{m}^{2}$ profile area). Many of them occur at sites not closely related to reproduction (basal nucleus of Meynert, the sublenticular substantia innominata, or the putamen). Because these regions are devoid of GnRH-immunoreactive (IR) somata, type-III GnRH neurons are unlikely to fully process the prohormone to the mature GnRH decapeptide and their role, if any, in reproduction is questionable.

\section{MORPHOLOGY OF GnRH NEURONS}

As in a variety of other mammalian species (11), the majority of human GnRH neurons are fusiform (12), with thin cell bodies and two processes emanating from the opposite poles of the neurons. A smaller subset of GnRH neurons is multipolar, with triangular or rounded cell body (15). Of note, while similar multipolar $\mathrm{GnRH}$ neurons were not observed in the first neuroanatomical studies of rodents, recent morphological characterization of biocytin-filled GnRH-green fluorescent protein (GFP) neurons revealed that 25\% of mouse GnRH neurons also have three or more dendrites, in addition to $15 \%$ that are unipolar and $65 \%$ that are bipolar (26).

\section{EFFERENT PROJECTIONS}

The postinfundibular eminence of the human hypothalamus plays a pivotal role in the secretion of releasing and release-inhibiting hormones (27). This anatomical site contains a superficial and a deep capillary plexus, both of which are drained into the hypophysial portal system and partly, also to the general circulation (27). Capillaries of both capillary networks are surrounded by GnRH-IR axons $(22,28)$, suggesting that the superficial and the deep vascular plexuses represent release sites for the hypophysiotropic GnRH axon terminals. It is important to note that the anatomical route of $\mathrm{GnRH}$ neurosecretion was reported to show considerable species variations. While in rats, most GnRH axons terminate in the external zone of the median eminence (7), in ferrets and bats a large subset enter the InfS and descend for a considerable distance (11). Similarly, the hypophysiotropic GnRH projections in the human and the monkey hypothalamus enter the InfS and travel all the way down to the neurohypophysis $(11,22)$. It is reasonable to assume that some GnRH secreted from these terminals reaches the adenohypophysis via the short portal veins.

In addition to hypophysiotropic axon projections, GnRH fibers innervate the organum vasculosum laminae terminalis (OVLT; although in much lower numbers than in the rat) (11), and the subfornical area (13). In the posterior hypothalamus, GnRH fibers surround the mamillary bodies (15). These fibers may already belong to a descending pathway described in various species which traverses the medial forebrain bundle to the ventral tegmental area and midbrain central regions (11). Other extrahypothalamic projection sites present at least in monkeys, include the habenula $(29,30)$ and the amygdala $(31)$, whereas $\mathrm{GnRH}$ projections to the hippocampus and the cingulate cortex have been better characterized in subprimates (11). Ultrastructural evidence exists from both rodents $(32,33)$ and non-human primates $(34)$ that the non-hypophysiotropic axons of $\mathrm{GnRH}$ neurons establish synaptic connections with other neurons.

\section{NETWORK CONNECTIVITY OF GnRH NEURONS}

The generation of rhythmic secretory bursts is assumed to require the coordinated secretory activity of GnRH neurons, although the underlying mechanisms are still poorly understood. The episodic secretion of GnRH from the GT1-7 GnRH cell line indicates that pulsatility may be an intrinsic property of GnRH neurons in which voltage-gated calcium channels and the connectivity of GT1-7 cell via gap junctions play important roles (35). Classical synapses interconnecting GnRH neurons have been detected in rats (32, 33) and also observed in non-human primates (34). Axo-somatic and axo-dendritic contacts between human GnRH-IR elements (15) suggest that similar synapses also exist in the human hypothalamus, although ultrastructural evidence for this is missing. An additional type of communication has been observed in rats and monkeys whose GnRH neurons form direct dendritic and somatic appositions with one another. At the ultrastructural level, regions of cytoplasmic confluence can be found at some of these contact sites (36). Occasional end-to-end dendritic continuity between neighboring pairs of GnRH neurons has also been observed with light microscopy in the human, indicating syntitium-like associations within a small subset of GnRH neurons (15). This type of connection may have its origins in the nose-to-tail orientation 
of migrating GnRH cells during embryogenesis (4). Recently reviewed (37) evidence from mice indicates that the dendrites of GnRH neurons form the morphological substrates for a critically important neural communication within the GnRH network. The majority of $\mathrm{GnRH}$ dendrites form bundles and intertwine with one another (38). Directly apposed dendrites often receive shared synaptic inputs (38) which may convey excitatory neuronal signals simultaneously to several dendrites. The dendritic tree of mouse GnRH neurons in the vicinity of the OVLT might be more complex than assumed previously. These processes appear to branch extensively in the OVLT which lies outside the blood-brain-barrier and hence, may be influenced by molecules circulating in the bloodstream (39). The synchronization of the GnRH network at the level of dendrites is a newly emerging possibility which gains importance from the observation that dendrites represent the primary sites of action potential generation in the mouse $\mathrm{GnRH}$ neuron (40). A final possibility for GnRH neurons to interact with one another is in the median eminence where GnRH terminals may communicate via additional autocrine signaling mechanisms.

\section{THE GnRH PULSE GENERATOR}

The human GnRH pulse generator has been localized to the mediobasal hypothalamus. Explants of this region from fetal and adult human brains release $\mathrm{GnRH}$ in a pulsatile manner (41). Recently accumulated evidence gave rise to the hypothesis that the mediobasal hypothalamus in several species contains putative pacemaker neurons that regulate the GnRH neurosecretory pulses. At least in some species, these cells ("KNDy neurons") cosynthesize KP, NKB, and dynorphins (42-44), whereas a subset of them in the human co-synthesize KP, NKB, and Substance P (SP) (45).

\section{NEURONAL INTERACTIONS OF GIRH NEURONS AXO-SOMATIC AND AXO-DENDRITIC INPUTS TO GnRH CELLS}

Results of ultrastructural studies in rats $(36,46)$ and monkeys $(36,47)$ established that GnRH neurons are innervated relatively sparsely, compared with other unidentified neurons located in the same anatomical regions. Quantitative analysis of serial ultrathin sections identified 2-12 synapses per GnRH neuron in male rats and 2-8 synapses in ovariectomized or estrogen-treated female monkeys (36). In post mortem human tissue samples, the relatively poor preservation of the ultrastructure only enables light- and confocal microscopic analyses of axo-somatic and axodendritic afferent contacts. Given that the resolution of these methods does not allow the identification of synaptic specializations, many of the observed contacts (juxtapositions) might not be actual synapses. Previous efforts to quantitatively assess the abundance of afferents could thus overestimate some of the specific inputs. Even with this in mind, monoaminergic, and several types of peptidergic neuronal contacts only occur sparsely on human GnRH neurons. A previous review (25) of neuropeptide Y (NPY), SP, beta-endorphin, leu-enkephalin, corticotrophin-releasing hormone $(\mathrm{CRH})$, and galanin containing, and tyrosine hydroxylase (TH)-IR, catecholaminergic inputs reveals general trends in the innervation pattern of single subclasses of GnRH neurons. Accordingly, while GnRH neurons in the septal area do not receive inputs from the above systems and GnRH neurons in the posterior hypothalamus are innervated occasionally only, the heaviest innervation of $\mathrm{GnRH}$ neurons can be observed in the infundibulum, followed by the preoptic area. In other studies, only a subset (about 50\%) of GnRH-IR neurons were found to receive histaminergic appositions (48) and similarly, KP-IR appositions were only observed on $54 \%$ of GnRH neurons in the Inf of young men (49). Even GnRH neurons of the infundibular region with the heaviest SP-IR input were typically innervated lightly; $45 \%$ did not receive SP-IR appositions, $37 \%$ received only $1-3$ contacts and only $18 \%$ received more than three contacts per perikaryon $(25,50)$. Out of the afferent systems of human GnRH neurons studied so far, the most abundant inputs seem to be given off by $\gamma$-aminobutyric acid (GABA)ergic and glutamatergic neurons. The mean incidence of light microscopic contacts established by GABAergic axons onto GnRH-IR somata was 45, whereas the VGLUT1 and VGLUT2 subclasses of glutamatergic axons established about 15 and 23 contacts, respectively, per GnRH-IR soma. Amino acidergic contacts were also encountered frequently on the dendrites of $\mathrm{GnRH}$ neurons where the combined incidence of glutamatergic contacts (over six contacts/10 $\mu \mathrm{m} \mathrm{GnRH}$ dendrite) somewhat exceeded the incidence of GABAergic appositions (over five contacts $/ 10 \mu \mathrm{m}$ GnRH dendrite) (51). It is important to emphasize that synaptic communication may not occur at a considerable subset of these light microscopic contacts.

The published data, overall, suggest that the innervation of human GnRH neurons is similarly sparse in the human as reported in rodents and monkeys (except for the relatively abundant amino acidergic inputs). On the other hand, immunohistochemical studies could also underestimate the real abundance of synaptic inputs (especially, on somatic and dendritic spines), considering that GnRH immunoreactivity does not necessarily visualize all postsynaptic sites that belong to GnRH neurons. Recent studies of biocytin-filled mouse GnRH neurons provide evidence for dendritic and somatic spines (26), which may provide additional postsynaptic membrane surfaces for excitatory inputs, as elsewhere in the central nervous system (52). Assuming the existence of similar GnRH-immunonegative somatic and dendritic spines in the human, the density of inputs, especially by excitatory afferents that preferentially target the dendritic spines, might be more abundant than indicated by the light microscopic immunohistochemical images.

\section{AXO-AXONAL COMMUNICATION}

Immediate axonal contacts on GnRH-IR hypophysiotropic fibers have been observed with confocal or electron microscopy in the median eminence of several species. Given that such axo-axonal contacts typically lack synaptic specializations at the ultrastructural level $(53,54)$, their significance may be difficult to appreciate, unless also supported by receptor localization and/or functional data. For example, GnRH terminals in the median eminence of the rat are apposed to glutamatergic axons $(54,55)$, contain the KA2 and NR1 ionotropic glutamate receptor subunits (54) and glutamatergic drugs induce $\mathrm{Ca}^{2+}$-dependent $\mathrm{GnRH}$ release from median eminence fragments in rats (56), indicating together the existence of paracrine communication between glutamatergic and GnRH axon terminals. Many peptidergic systems may also be 
involved in similar axonal regulation of GnRH secretion. Direct appositions exist between NKB-IR and GnRH-IR axons $(53,57)$ of the rat which latter express immunoreactivity for the NKB receptor NK3 (57). Furthermore, KP-IR fibers are also apposed to GnRH-IR axons in the goat (58) and the monkey (59) median eminence and such appositions appeared to be frequent compared with axo-somatic and axo-dendritic inputs.

Although interactions at the level of the $\mathrm{GnRH}$ axon likely have high functional significance, there are only relatively few reports on similar axo-axonal appositions in the human postinfundibular eminence. We found that KP-IR axons establish such axo-axonal contacts on GnRH-IR fibers in humans (60) and many of these KP fibers also contain NKB and SP (45), increasing further the complexity of possible autocrine/paracrine interactions in the human postinfundibular eminence. While the presence of KP receptor (KISS1R) on GnRH terminals has not been demonstrated formally, there is abundant indirect evidence both from animal and human studies to suggest that the GnRH terminal is an important physiological site of KP action via KISS1R in the regulation of pulsatile GnRH secretion. (i) First, KP can stimulate GnRH release from median eminence fragments of wild type, but not Kiss $1 R$ mutant, mice (61). This in vitro action of KP is independent of action potential generation as it persists in the presence of tetrodotoxin (61). (ii) Second, in vivo release of KP into the monkey median eminence is pulsatile and KP peaks coincide with the LH secretory pulses (62). (iii) Third, peripheral injection of $\mathrm{KP}$, which does not cross the blood-brain-barrier, results in a rapid increase of LH release (63-67), suggesting that KP acts on $\mathrm{GnRH}$ projections in circumventricular organs. Characterization of axonal neuropeptide receptors will be required in order to clarify the putative autocrine and paracrine interactions that regulate pulsatile GnRH secretion. Unfortunately, the immunohistochemical detection of receptor proteins in post mortem tissue samples is most often compromised by the suboptimal tissue processing conditions.

\section{EFFERENT TARGETS}

Ultrastructural evidence exists from both rodents $(32,33)$ and monkeys (34) that GnRH-IR axons establish synaptic contacts with other GnRH neurons; these synapses exhibit symmetric specialization. GnRH/GnRH contacts were also observed in the human with the light microscopic analysis of immunolabeled specimens (15).

Relatively little information is known about further postsynaptic target neurons of GnRH-IR axons. Light microscopic observations indicate that the communication between galaninergic and GnRH neurons in the human hypothalamus is bidirectional. The incidence of GnRH-IR inputs to galanin-IR neurons was reported to be highest in the infundibular region (68).

\section{NEUROPEPTIDES AND CO-TRANSMITTERS IN GnRH NEURONS}

Classical neurotransmitters and neuropeptides co-contained in GnRH neurons may considerably modulate GnRH secretion from hypophysiotropic GnRH axon terminals and/or influence the hypothalamic and extrahypothalamic synaptic communication of GnRH-IR axon projections.
While prenatally, rodent GnRH neurons exhibit immunoreactivity to $\gamma$-aminobutyric acid (69), in adult rats GnRH neurons express the mRNA and protein of the glutamatergic marker type2 vesicular glutamate transporter (VGLUT2) (70). A previous study in our laboratory also addressed this putative glutamatergic phenotype of human GnRH neurons but found no evidence for VGLUT2 immunoreactivity in GnRH-IR axon terminals in the InfS (51). This negative colocalization result may have both biological and technical explanations and the amino acid phenotype of human GnRH neurons remains to be established.

In laboratory animals, $\mathrm{GnRH}$ neurons were also found to contain neuropeptide co-transmitters/neuromodulators. A high degree of colocalization has been observed between galanin-IR and GnRH-IR neuronal elements of the rat $(71,72)$, mouse (73), and sheep (74). The coexpression of galanin in rat GnRH neurons is highly sexually dimorphic and estrogen-dependent (75). Intrinsic galanin may partly act on GnRH neurons via Gal-R1 autoreceptors expressed in GnRH neurons (76). In addition to containing galanin, GnRH neurons in the rat also express cholecystokinin and neurotensin immunoreactivities in sexually dimorphic manners (77). In contrast, the galanin colocalization phenomenon has not been observed in the human hypothalamus (68). Moreover, no successful neuropeptide colocalization has been reported for human GnRH neurons to date.

\section{ESTROGEN SIGNALING TO GnRH NEURONS}

Changing levels of the ovarian sex steroid hormone E2 regulate the activity of the neuroendocrine reproductive axis through feedback actions to GnRH neurons (78). In 1983, Shivers et al. (79) reported that GnRH neurons of the rat do not accumulate tritiated E2 in vivo. Moreover, subsequent immunohistochemical studies also failed to detect the classical " $\alpha$ " form of estrogen receptor $(E R \alpha)$ in GnRH neurons $(80,81)$. These observations formed the basis of a prevailing view that most actions of estrogens are communicated to the GnRH neuronal system by estrogen-sensitive neuronal and/or glial elements.

\section{DIRECT ESTROGEN SENSITIVITY}

Soon after the discovery of a second ER isoform (ER $\beta$ ) in 1996 (82), the absence of direct estrogen feedback to GnRH neurons was challenged by the observations of ER $\beta$ mRNA expression $(83,84), \mathrm{ER} \beta$ immunoreactivity $(85,86)$ and ${ }^{125}$ I-estrogen-binding sites $(83)$ in rodent GnRH neurons. The finding of ER $\beta$, but not ER $\alpha$, transcripts in rodent GnRH neurons using RT-PCR (87) and in situ hybridization (83) techniques suggested that $\operatorname{ER} \beta$ is the dominant ER isoform involved in direct estrogen feedback to GnRH neurons. This conclusion does not seem to be valid only to rodents, in view that immunohistochemical studies also localized ER $\beta$ to a large subset of ovine GnRH neurons (88) which, similarly to the GnRH neurons in other species, lack ER $\alpha$ immunoreactivity (89).

Dual-label immunohistochemical studies from our laboratory also identified ER $\beta$ immunoreactivity in $11-28 \%$ of GnRH neurons in adult human males (90). In the light of the earlier in situ hybridization evidence for the absence of detectable ER $\alpha$ mRNA levels in these cells (90), direct estrogen actions onto human $\mathrm{GnRH}$ neurons might be mediated exclusively by the ER $\beta$ receptor form. 
Functional evidence mostly exists from rodents in support of direct $\operatorname{ER} \beta$ mediated estrogen effects onto GnRH neurons, as reviewed recently (91). For example, upon ligand binding, ER $\beta$ can cause rapid phosphorylation of cAMP-response element-binding protein $(91,92)$ and stimulate intracellular calcium oscillations (93) via exerting non-genomic effects on mouse GnRH neurons. In addition, $\operatorname{ER} \beta$ mediates a ligand-independent transcriptional activation and a ligand-dependent transcriptional repression of the mouse GnRH promoter in in vitro transfection experiments (94). Furthermore, ER $\beta$-selective agonists can induce galanin mRNA expression in GnRH cells of ovariectomized rats in vivo (95), possibly via an ER $\beta$-mediated direct action. The contribution of ER $\beta$-mediated direct estrogen effects to the regulation of human GnRH neurons (90) requires clarification.

It has to be emphasized that although the selective presence of the ER $\beta$ isoform in GnRH cells appears to be conserved in different mammalian species, the indirect effects of $\mathrm{E} 2$ that are mediated to $\mathrm{GnRH}$ cells by $\mathrm{ER} \alpha$ containing interneurons clearly dominate in the regulation of reproduction over the ER $\beta$-mediated direct effects. Accordingly, both negative and positive estrogen feedback mechanisms are disrupted in the ER $\alpha$-knockout mice (96) and human case reports also exist to show that the disruption of $\mathrm{ER} \alpha$ signaling causes profound estrogen resistance in women, with delayed puberty and the absence of menstrual cyclicity (97).

\section{ESTROGEN-SENSITIVE INTERNEURONS OF THE INFUNDIBULAR REGION}

The hypothalamic ARC (Inf) has long been considered as an important site of sex steroid negative feedback to the reproductive axis. The absence of this negative estrogen feedback in postmenopausal women causes profound anatomical changes in the human Inf, with a robust hypertrophy of ER $\alpha$ (24), SP (98), NKB (98), KP (99), and prodynorphin (100) expressing cells. Morphological alterations are accompanied by increased NKB (98)-, KP (99)-, and SP (98)- and decreased prodynorphin (100) mRNA synthesis. The high levels of KP and NKB immunoreactivities detectable in the Inf of postmenopausal women (101) support the notion that the inhibitory control of KP and NKB synthesis in these cells is diminished in the absence of E2.

Recent experimental evidence from animal studies confirm that the role of $\mathrm{KP} / \mathrm{NKB}$ neurons is critical in gonadal steroid feedback to GnRH neurons in both sexes and in various species. Of note, the ablation of these cells in rats with locally applied microinjection of the NK3-saporin neurotoxin prevented the rise in serum LH and attenuated the rise in serum FSH following ovariectomy (102). The estrogenic suppression of gonadotropin secretion has not been entirely blocked in the lesioned rats, indicating also some redundancy of the neuronal pathways mediating the negative feedback effects of estrogens (102). It is worth to note that the ablation of the same KP/NKB cell group in the ARC also interfered with the estrogenic suppression of body weight (102). Furthermore, these cells appear to also convey important estrogen signals to the thermoregulatory centers. It is hypothesized that the dysregulation of this signaling during menopausal transition is also involved in the pathogenesis of hot flushes (103).

\section{POSSIBLE ROLE FOR THE ROSTRAL PERIVENTRICULAR REGION}

Recent immunohistochemical work from our laboratory identified a relatively compact KP cell population in the rostral periventricular region of premenopausal women but not in men (60). The distribution of these neurons overlapped with the ventral periventricular nucleus, the anterior parvicellular paraventricular nucleus and the parvicellular and magnocellular subdivisions of the paraventricular nucleus, according to the anatomical atlas of Mai et al. (104). A more thorough characterization of this cell population will require the further investigation of tissues samples from male and female individuals of different ages.

Spontaneous menstrual cyclicity and LH/FSH responses to estrogen are well-preserved after the mediobasal hypothalamic deafferentation of non-human primates (105) and E2 can also elicit gonadotropin surges after acute complete removal of the neural tissue dorsal and anterior to the optic chiasm (106). These data support the prevailing view that positive sex steroid feedback in primates takes place exclusively in the infundibular region (107). The presence of a sexually dimorphic nucleus and KP cell group in the human rostral periventricular region raises a challenge to this view.

\section{AFFERENT INPUTS TO GnRH CELLS NEUROPEPTIDES Neuropeptide $Y$}

The 36-amino acid peptide NPY acts at multiple levels of the reproductive axis to influence gonadotropin secretion. At the hypophysial level, it potentiates $\mathrm{LH}$ secretion in response to a GnRH challenge by modulating GnRH binding to anterior pituitary GnRH receptors (108). At the level of the median eminence, it stimulates GnRH secretion from GnRH axon terminals (109, 110). Finally, an important site of central NPY actions might be on the somato-dendritic compartment of GnRH neurons. The majority of GnRH neurons in the rodent preoptic area receive abundant innervation from NPY-containing axon terminals (111, 112) and express the Y5 receptor form (113). At least two separate sources exist in rodents for the NPY-IR inputs to GnRH neurons. Retrograde labeling of NPY neurons has been observed in both the ARC and the ventrolateral medulla following retrograde tracer injection around GnRH neurons (114). In a previous study from our laboratory we used two site-specific neurochemical markers to determine the relative contribution of these two cell populations to the innervation of GnRH neurons (115). About half of the NPYIR contacts on $\mathrm{GnRH}$ cells also contained agouti-related peptide, indicating their origin in the ARC where the two peptides are co-synthesized in the same neurons (116). A further one-fourth of the contacts contained the noradrenergic/adrenergic marker enzyme dopamine- $\beta$-hydroxylase (115), indicating the origin of these inputs in brainstem catecholamine cell groups (117). The source of the remaining one-fourth of the NPY fibers making contacts with GnRH neurons, requires clarification.

Neuropeptide Y plays an important role in the central regulation of the reproductive axis, in particular, in the metabolic regulation of fertility (118). While a chronic increase in NPY tone inhibits gonadotropin release (119), delays sexual maturation (120), and suppresses estrous cyclicity (121), the direction of acute NPY effects depends markedly on the sexual steroid status. 
For example, while in castrated animals, central administration of NPY decreases gonadotropin secretion $(122,123)$, in intact rodents or gonadectomized and steroid-primed rodents, NPY increases serum levels of gonadotropins $(119,124)$. Among the multiple and potentially redundant peptidergic pathways that mediate metabolic effects on the reproductive axis (118), the functional significance of the direct NPY input to GnRH neurons requires clarification.

In the human, NPY-IR varicosities establish similar axosomatic and axo-dendritic contacts with GnRH-IR cell bodies and dendrites as in rodents. Individual GnRH neurons are often contacted by multiple axonal swellings (15). Juxtapositions are most numerous in the Inf, followed by the medial preoptic region and then, the anterior periventricular nucleus (15). The sources of NPY axons innervating human GnRH neurons needs to be determined using similar region-specific phenotype markers as earlier studies on mice (115).

\section{Substance $P$}

Substance $\mathrm{P}$ is an eleven-amino acid-neuropeptide derived from the preprotachykinin A gene, which exhibits the highest affinity to the G protein-coupled NK1 receptor, whereas neurokinin A, another derivative of the same gene, acts via the NK2 receptor (125). As reviewed recently, SP can influence reproduction at the hypothalamic, pituitary, and gonadal levels of the reproductive axis (126). Previous studies identified both inhibitory and excitatory $\mathrm{LH}$ responses to SP. For example, SP can inhibit the GnRHstimulated secretion of LH from cultured human pituitary cells (127). On the contrary, intravenous, or intracerebroventricular SP injection to ovariectomized estrogen primed rats stimulates, and conversely, intracerebroventricular application of a SP antiserum to ovariectomized rats inhibits LH release (128).

An important site of hypothalamic SP synthesis is the ARC/Inf. The SP system of the rat ARC shows morphological changes across the estrous cycle, with maximal IR cell numbers detected at proestrus/estrus $(129,130)$. SP-IR axons originating partly from this nucleus form synaptic contacts with $\mathrm{GnRH}$ neurons of the preoptic region (131). Preprotachykinin A mRNA expression (98) and SP immunoreactivity $(50,132)$ have also been revealed in neuronal cell bodies of the human Inf. Similarly to the rat SP neurons, these cells appear to be estrogen-sensitive, as indicated by their hypertrophy and enhanced mRNA expression in postmenopausal women in the absence of estrogens (98).

Substance $\mathrm{P}$ neurons of the human infundibular region may influence reproduction via multiple actions, depending on the currently unknown site/s of location of its main receptor, NK1. Important hypothalamic effects may be exerted through SP-IR axo-somatic and axo-dendritic contacts identified on GnRH neurons (50). The NK1 receptors underlying this communication may either be pre- or postsynaptic. SP neurons appear to form a network within the Inf; they may regulate one another via the frequently encountered axo-somatic and axo-dendritic contacts (50) that are reminiscent of a similar networking among the NKB neurons in laboratory animals (133). NKB-signaling through these $\mathrm{NKB} / \mathrm{NKB}$ contacts use $\mathrm{NK} 3$ autoreceptors and this communication has been recently implicated in the mechanism of pulsatile GnRH/LH secretion $(42,43,134)$. In humans, SPIR neurons densely innervate the neurovascular zone of the InfS
(132). These projections may be involved in important axo-axonal interactions and may also serve as the major source of SP in the portal circulation to exert adenohypophysial actions (127).

The distribution of SP and NKB neurons in the human Inf is very similar (98). Recent immunohistochemical evidence from our laboratory indicates that considerable subsets of KP-IR $(30.6 \%)$ and NKB-IR $(25.1 \%)$ neurons in the Inf of postmenopausal women also contain SP immunoreactivity (45). This interesting colocalization phenomenon has not been reported so far in laboratory animals and thus, might only exist in certain species. The presence of SP in NKB and KP neurons increases the functional complexity of the putative pulse generator network thought to be localized in the ARC/Inf. From the functional view-point, it is possible that SP modulates the effects of $\mathrm{KP}$ and $\mathrm{NKB}$ in axosomatic and axo-dendritic afferents to GnRH neurons. Intrinsic SP may also exert autocrine/paracrine actions via autoreceptors to regulate the activity and/or neuropeptide release of NKB/SP and KP/SP neurons. In the InfS, SP may either influence the KP and NKB secretory output via autocrine/paracrine mechanisms or regulate $\mathrm{GnRH}$ neurosecretion directly. Finally, possible co-release of SP with KP and NKB into the portal circulation could underlie further interactions on adenohypophysial gonadotrophs.

\section{Galanin}

Galanin is a 29-amino acid peptide (135). It is widely distributed in the central nervous system and acts as a transmitter, modulator, and growth factor in a number of physiological and disease-related processes (136).

Galanin regulates rodent reproduction partly via acting in the adenohypophysis. First, it is synthesized locally in the anterior pituitary (137). In addition, hypothalamic galanin also reaches gonadotroph cells via the hypophysial portal circulation (138). Galanin is secreted into the portal blood in a pulsatile manner (138) and enhances GnRH receptor binding on gonadotroph cells (139). The main hypothalamic sources of galanin in the portal blood of the rat are the ARC and the paraventricular nucleus (140). The scattered galanin neurons in the medial preoptic area that project to the median eminence correspond to GnRH neurons which express galanin in a sexually dimorphic and estrogen-dependent manner (141).

Galaninergic neurons also regulate reproduction at the level of the hypothalamus in rats (71) and mice (142), partly via providing direct innervation to GnRH neurons.

The anatomical relationship of galanin-IR and GnRH-IR neurons in the human hypothalamus has been studied with dual-label immunohistochemistry. A detailed topographic study localized the majority of galaninergic neurons posteriorly to the lamina terminalis. Densely packed galanin-IR cell bodies were present in high numbers in the infundibulum and were often located around the portal capillary vessels. Numerous IR perikarya were detected at the basal surface of the tuberal region, extending from the Inf to the optic tract. Many galanin-IR perikarya were detected in the periventricular and paraventricular nuclei and in the chiasmatic and tuberal regions (68).

Dual-label immunohistochemical studies of post mortem human hypothalamic sections identified a bidirectional communication between galanin and GnRH neurons (68). Galanin-GnRH and GnRH-galanin juxtapositions were most numerous in the 
medial preoptic area and in the infundibulum/median eminence (68). These contacts were proposed to represent the major morphological substrate of the galanin-controlled gonadal functions in humans. The issue of which galaninergic cell populations are involved in the innervation of human GnRH neurons requires clarification.

\section{Corticotropin-releasing hormone}

There is a large body of evidence to suggest that central corticotropin-releasing hormone $(\mathrm{CRH})$ signaling plays a crucial role in the stress-induced suppression of the GnRH pulse generator. For a recent review, see Li et al. (143). Intracerebroventricular administration of CRH inhibits multiunit activity volleys in monkeys (144). It also decreases LH pulse frequency in rats (145). Furthermore, the suppression of LH pulses by insulininduced hypoglycemic stress can be completely prevented by intracerebroventricular administration of a CRH antagonist (145).

Some of the suppressive effects of central CRH signaling might be exerted directly on $\mathrm{GnRH}$ neurons which receive synaptic inputs from CRH-IR structures in the rat hypothalamus (146). The source of this innervation is, however, unclear, in view that CRH-IR axons might arise from multiple brain sites, including the hypothalamic paraventricular nucleus, the bed nucleus of the stria terminalis and the central amygdala, among many other regions.

Juxtaposition of CRH-IR fibers to GnRH neurons has also been observed in the human hypothalamus (147). Similarly to a series of other specific inputs (25), these neuronal contacts were most frequently encountered in the infundibular region (147).

\section{Kisspeptin}

Kisspeptin signaling via its specific receptor (KISS1R) plays critically important roles in the regulation of puberty and reproduction. Inactivating mutations of the encoding KISS1 (148) and $\operatorname{KISS1R}(149,150)$ genes, respectively, cause hypogonadotropic hypogonadism in humans. Today's consensus is that KP neurons regulate reproduction mainly via stimulating hypothalamic $\mathrm{GnRH}$ secretion. In different mammalian species, GnRH neurons are innervated by KP-IR afferents $(59,60,151,152)$, express Kiss1R mRNA $(153-155)$, and respond with Fos expression $(63,154)$ and depolarization (155-157) to KP.

The topographic distribution, network connectivity, neurochemistry, sexual dimorphism, and aging-dependent morphological plasticity of the human hypothalamic KP neuronal system have been analyzed in a series of recent morphological studies. Both in situ hybridization (99) and immunohistochemical (60) studies localized the majority of KP synthesizing neurons to the Inf and the InfS. Immunohistochemical studies of young female subjects also detected a more lightly stained second KP cell group in the rostral periventricular area of the third ventricle (RP3V) (60). A smaller third KP cell population consisting of darkly labeled neurons is scattered periventricularly at all rostro-caudal levels of the medial hypothalamus (60).

The axons of KP neurons establish contacts with the cell bodies, dendrites, and hypophysiotropic fiber projections of $\mathrm{GnRH}$ neurons (60). These appositions are thought to represent the primary sites of KP action on the reproductive axis. As mentioned in later sections, the incidence of such appositions shows considerable plasticity, being higher in postmenopausal women compared with age-matched men (101) or in aged, compared with young men (49).

The exact role of the distinct KP cell populations in human reproduction requires clarification. In rodents, the RP3V encloses a higher number of KP neurons in females than in males (152, 158, 159 ) and there is strong case that these KP neurons are critically involved in positive estrogen feedback to GnRH neurons (160). Both in female rodents $(159,161)$ and sheep $(162,163)$ the preoptic KP neurons are activated before the preovulatory $\mathrm{GnRH} / \mathrm{LH}$ surge. The presence of a sexually dimorphic "RP3V"-like nucleus and KP cell population in humans (60) raises a challenge to the prevailing view that positive sex steroid feedback in primates takes place exclusively in the infundibular region (107).

Independently from the species, $\mathrm{KP}$ neurons of the ARC/Inf have been implicated in the negative feedback effects of gonadal steroids to GnRH neurons (164-166) and their neurotoxic ablation in rats, indeed, prevented the rise in serum $\mathrm{LH}$ and attenuated the rise in serum FSH following ovariectomy (102). In sheep and possibly in primates, KP neurons of the ARC may also play a role in positive estrogen feedback to GnRH neurons. Both ovariectomy and a surge-inducing E2 treatment could induce Fos expression in KP neurons of the sheep ARC (167). In addition, KP neurons of the hypothalamic ARC/Inf may represent an important constituent of the hypothalamic pulse generator which regulates the episodic secretion of GnRH into the hypophysial portal circulation. Recent models $(42,43,168,169)$ hypothesize that the intranuclear network communication of these KP neurons uses other colocalized neuropeptides and their autoreceptors, whereas KP provides the major output signal toward GnRH neurons.

\section{Neurokinin B}

Unlike the preoptic KP cell population, KP neurons in the sheep (164, 168), goat (43), mouse (42), and monkey (170) ARC also synthesize the tachykinin peptide NKB. The majority of human $\mathrm{KP}$ neurons in the Inf have also been shown to contain $\mathrm{NKB}$ immunoreactivity (60), although the inverse colocalization pattern (incidence of KP expression in NKB neurons) in humans shows considerable sex- and age-dependencies $(49,101)$. Similarly to KP, NKB plays a crucial role in the regulation of puberty and reproduction. Inactivating mutations of the genes encoding for NKB (TAC3) or the NKB receptor NK3 (TACR3) cause hypogonadotropic hypogonadism in the human $(171,172)$ KP neurons of the ARC in various mammalian species also contain the NK3 autoreceptor $(42,57,133,173)$. NKB-signaling via the NK3 autoreceptor can significantly modulate the frequency of the GnRH neurosecretory pulses. For example, central administration of NKB increases the frequencies of multiunit activity volleys and LH secretory pulses in ovariectomized goats, likely via acting on this NK3 autoreceptor (43).

The issue of whether or not, NKB influences GnRH neurons directly, is controversial. GnRH-IR axons are apposed to NKB-IR axons in the rat median eminence $(53,57)$ where GnRH fibers express NK3 immunoreactivity (57). Somewhat conflictingly, mouse GnRH neurons do not show electrophysiological responses to the NK3 agonist Senktide (174).

We note that human NKB neurons in the infundibular region outnumber KP neurons in all human models that we examined so far with immunohistochemistry $(28,49,60,101)$. The largest 
difference was noticed in young human males where only $33-36 \%$ of the NKB neurons expressed KP immunoreactivity (49). This low colocalization percentage then increased to $68 \%$ in aged male individuals (49).

Similarly to KP neurons (60), NKB neurons in the human hypothalamus form afferent contacts with the somatic, dendritic, and axonal compartments of GnRH neurons $(28,49,101)$. Interestingly, the incidence of NKB-IR contacts onto $\mathrm{GnRH}$ neurons is significantly higher than that of KP-IR inputs, and depending on the human model, only $10-30 \%$ of the KP-IR and NKB-IR inputs to $\mathrm{GnRH}$ neurons were found to be double-labeled for the other peptide $(49,101)$. The identity of neurotransmitter(s) used in this communication and, the putative involvement of $\mathrm{NKB} / \mathrm{NK} 3$ signaling, require clarification.

\section{Endorphins}

Endogenous opioid peptides are important central inhibitors of the reproductive axis. Since the opiate antagonist naloxone had no direct influence on pituitary release of $\mathrm{LH}$ and the $\mathrm{LH}$-releasing effect of systemic naloxone treatment could be prevented with GnRH antagonist in rats, the effects of opioid peptides are likely mediated by the GnRH neuronal system (175).

Microinjection of the proopiomelanocortin gene-derived opioid peptide $\beta$-endorphin into the mediobasal hypothalamus and the medial preoptic area, the major sites of location of GnRHIR elements, significantly suppressed LH secretion in rats (176). Conversely, administration of $\beta$-endorphin antiserum into these areas elevated LH secretion (177). In contrast, when hemipituitaries of ovariectomized rats were incubated in vitro with $10^{-7}$ $\mathrm{M} \beta$-endorphin, basal, or GnRH-induced LH release was not suppressed (176). The above data, together lead to the conclusion that $\beta$-endorphin acts at a medial hypothalamic and/or preoptic-septal site and not the pituitary, to alter secretion of $\mathrm{LH}$.

At least some of the effects of $\beta$-endorphin on GnRH neurons might be exerted through the direct synaptic connectivity of the two systems reported both in juvenile female monkeys (34) and in male rats (33). The authors of the rodent study reported the presence of $\beta$-endorphin in $10 \%$ of synaptic afferents to $\mathrm{GnRH}$ neurons (33).

Light microscopic contacts have also been observed between $\beta$ endorphin-IR axons and GnRH-IR neurons in the human where the contacts were most abundant in the infundibular region (178). The $\beta$-endorphin-IR input to human GnRH neurons is likely to arise from local sources given that the mediobasal hypothalamus contained a high number of $\beta$-endorphin-IR perikarya (178). Interestingly, while a series of immunohistochemical studies showed that GnRH neurons in front of the lamina terminalis do not receive significant input from axons containing catecholamines (179), NPY (15), SP (50), leu-enkephalin (180), and $\mathrm{CRH}$ (147), $\beta$-endorphin containing axons did innervate this rostral subpopulation of GnRH neurons (178).

\section{Enkephalins}

The preproenkephalin gene-derived opioid peptides leuenkephalin and met-enkephalin can modulate pituitary LH release via direct actions at the pituitary level. Although enkephalins alone have no effect on LH release in vitro, they can potentiate the LH response to GnRH (181). The effects of enkephalins on the reproductive axis appear to be indirect and mediated by GnRH neurons. Multiple enkephalinergic systems may contribute to this regulation. One of such systems identified in the mouse RP3V co-expresses KP (182). These KP neurons are more numerous in females compared with males (152) and they have been implicated in positive estrogen feedback to GnRH neurons in rodent species (160). The putative existence of an analogous enkephalin/KP cell group in the human rostral hypothalamus awaits clarification.

Direct regulatory actions of central enkephalinergic pathways on human GnRH neurons have been addressed with dual-label immunohistochemical studies (180). These experiments established that Leu-enkephalin-IR cell bodies are concentrated in three different regions: (i) in the periventricular area of the tuberal region, (ii) in the infundibulum in the close proximity of the portal vessels, and (iii) in the medial preoptic area periventricularly (180). Leu-enkephalin-IR fibers established appositions to GnRHIR cell bodies and dendrites mainly in the infundibulum and the median eminence (180).

\section{Dynorphins}

Kisspeptin and neurokinin B neurons of the ARC synthesize the opioid peptide dynorphin in the rat, mouse, sheep, and goat (42, $43,133,164,168)$, serving as the basis for the recently introduced "KNDy neuron" terminology (169). Central injection of dynorphin to ovariectomized goats decreases the frequencies of multiunit activity volleys and LH secretory pulses (43).

The Inf of the human hypothalamus also contains prodynorphin mRNA expressing neurons (100) and the majority of GnRH neurons in the human hypothalamus have close contacts with dynorphin fibers (183). While the existence of triple-neuropeptide phenotype KNDy neurons in the human Inf has been predicted from the animal data, a recent immunohistochemical study from our laboratory only found evidence for scattered KP/dynorphin dual-labeled axons in the Inf of young human male subjects, whereas most KP cell bodies and fibers were devoid of dynorphin immunoreactivity (28). It seems likely that these negative colocalization data reveal an important species difference of the human from laboratories species. Alternatively, partial post mortem degradation of dynorphin in KP-IR neuronal elements of the human Inf can not be entirely ruled out. Of note, preliminary data from our laboratory using well-preserved human tissues samples perfusionfixed within a few hours after death support the view that IR dynorphin A and dynorphin B can only be detected within very small subsets of KP-IR axons in the human infundibular region.

\section{RF-amide related peptides/gonadotropin-inhibiting hormone}

Gonadotropin-inhibiting hormone $(\mathrm{GnIH})$ plays a crucial role in the inhibitory regulation of the reproductive axis. In birds, $\mathrm{GnIH}$ appears to have at least two sites of action on the reproductive axis. First, it directly inhibits gonadotropin release from the pituitary in a dose-dependent manner (184). In addition, it occurs in neuronal afferents that form contacts with GnRH cells (185) which latter, contain receptors for GnIH (186). The putative GnIH homologs, RF-amide related peptides (RFRP-1, RFRP-2, RFRP-3), have been identified in mammals (187). Neurons synthesizing preproRFRP 
mRNA and RF-amide peptides have been localized mostly to the dorsomedial nucleus of the hypothalamus in hamsters, rats, mice, and sheep (188-193).

While it is generally agreed that GnIH/RFRP neurons in birds, rodents, ewes, and primates can act via regulating GnRH neurons $(185,190,192-195)$, the additional adenohypophysial site of action of RFRP peptides in mammals has been controversial. Despite in vitro evidence from several species for direct pituitary effects (196-198), GnIH/RFRP-IR terminals have only been observed in the neurosecretory zone of the median eminence in birds (184, 196, 199) and monkeys (200), but not in rodents (190, 192). Furthermore, RFRP synthesizing neurons in rats do not accumulate Fluoro-Gold from the systemic circulation, indicating lack of access to the hypophysial portal circulation (192).

There has only been one morphological report so far addressing the role of RFRPs in human reproduction (200). This study used affinity column purified rabbit anti-white-crowned sparrow $\mathrm{GnIH}$ antibodies for the immunohistochemical detection of GnIH-IR structures. This study came to the conclusion that IR cell bodies of the human are located in the dorsomedial nucleus, send axonal projections to GnRH neurons in the preoptic area as well as to the median eminence (200). Furthermore, RT-PCR and subsequent DNA sequencing of the PCR products identified human GnIH receptor (GPR147) mRNA expression in the pituitary and in situ hybridization confirmed its expression in LH producing gonadotropes (200). The future use of human RFRP-specific antibodies will be important to reproduce these interesting immunohistochemical findings which suggest that the RFRP system in the human may regulate reproduction both at the hypothalamic and the hypophysial levels.

\section{GnRH}

In rats $(32,33)$ and non-human primates (34), GnRH-IR axons establish symmetric synaptic contacts with one another at the ultrastructural level. This communication channel and autocrine/paracrine regulatory mechanisms have been implicated in a putative ultrashort loop feedback mechanism whereby $\mathrm{GnRH}$ inhibits the neuronal activity of GnRH neurons. In some studies the incidence of GnRH-IR synaptic inputs to $\mathrm{GnRH}$ neurons almost reaches $10 \%$ of all synaptic inputs (33).

Human GnRH neurons also establish axo-somatic and axodendritic appositions with one another at the light microscopic level (15), which may correspond to synaptic connections.

\section{Other peptidergic systems}

Many further peptidergic systems exert direct regulatory actions on GnRH neurons in laboratory animals. Some of the specific inputs are derived from lateral hypothalamic peptidergic neurons and their neurotransmitters/neuromodulators include melanin concentrating hormone (194) and orexin $(201,202)$. Other afferents contain cocaine and amphetamine regulated transcript (203). The existence of analogous neuronal connections in the human hypothalamus will require clarification.

\section{MONOAMINES}

While the role of serotonin in the afferent control of GnRH neurons has not been addressed in the human, anatomical evidence exists to support the role of catecholamines and histamine in the afferent control of human GnRH neurons.

\section{Catecholamines}

Different catecholamines exert wide effects on LH release mostly via central actions (204-207), although evidence also exists for the hypophysial site of catecholamine actions (208).

Catecholamines of hypothalamic and extrahypothalamic origins partly modulate gonadal functions via direct interactions with hypothalamic GnRH neurons. Earlier studies on rodents identified appositions between catecholaminergic fibers and GnRH-IR cell bodies in rats (209) and mice (115).

In a previous study (179), the distribution of GnRH-IR and TH-IR structures and their neuronal interactions were also addressed in the human diencephalon. This study identified TH-IR dopaminergic perikarya in the periventricular, paraventricular, and supraoptic hypothalamic nuclei and also in the median eminence. The TH-IR fibers were numerous in septal, infundibular, periventricular, and lateral hypothalamic regions. GnRH neurons in the infundibular and medial preoptic areas received $\mathrm{TH}$-immunopositive axon contacts, whereas GnRH-IR perikarya only received a few juxtapositions in the preoptic area and the caudal parts of the diencephalon. Because TH is also required for the synthesis of epinephrine and norepinephrine in the brain stem, these catecholaminergic inputs could arise from various dopaminergic, adrenergic, and noradrenergic cell groups. The contribution of different catecholamines to the afferent regulation of human $\mathrm{GnRH}$ neurons will thus require clarification.

\section{Histamine}

E2 increases histamine release from hypothalamic tissue blocks in vitro (76), histaminergic neurons provide abundant input to the preoptic area (210) which also contains GnRH neurons, intracerebroventricular injection of histamin causes ovulation in rabbits (211) and the immortalized GT1-7 neuronal cell line expresses H1 histamine receptors (212). Based on these data and in search for neuronal systems that might mediate the feedback effects of E2 to GnRH neurons, we investigated the possible role of the histaminergic neuronal system in rats and humans (48).

Results of our studies on rats (48) showed that $66-81 \%$ of histaminergic neurons in all subdivisions of the tuberomamillary complex contained nuclear ER $\alpha$ immunoreactivity. Histaminergic axons in the preoptic region established axo-dendritic and axosomatic contacts with GnRH-IR neurons. Finally, lateral ventricular infusion of the $\mathrm{H} 1$ receptor antagonist mepyramin inhibited the estrogen-induced surge of $\mathrm{LH}$, whereas the $\mathrm{H} 2$ receptor antagonist ranitidin was without effect.

The putative human relevance of these data was addressed via the immunohistochemical analysis of histaminergic neuronal contacts onto human GnRH neurons. $51 \pm 3.0 \%$ of GnRH neurons in these studies were found to receive histamin-IR axonal appositions (48). In other studies, both the $\mathrm{ER} \alpha$ and the $\mathrm{ER} \beta$ receptor isoforms have been localized to the human tuberomamillary complex with immunohistochemistry (213). The above data indicate that the positive feedback effect of E2 on the preovulatory LH surge may involve estrogen-receptive histamine-containing neurons within 
the tuberomamillary regions which communicate with $\mathrm{GnRH}$ neurons via $\mathrm{H} 1$ receptors.

\section{AMINO ACID NEUROTRANSMITTERS}

The most abundant inhibitory and excitatory neurotransmitters in the hypothalamus are GABA (214) and glutamate (215), respectively.

\section{$\gamma$-Aminobutyric acid}

Based primarily on evidence from studies of laboratory rodents, GABA is thought to represent the principal neurotransmitter in the synaptic control of GnRH neuronal functions (216). Such studies showed that GnRH neurons receive an abundant GABAergic synaptic input (217), express functional receptors for both the ionotropic $\mathrm{GABA}_{\mathrm{A}}(218-220)$, and the metabotropic $\mathrm{GABA}_{\mathrm{B}}$ (221) receptors and all of them exhibit $\mathrm{GABA}_{A}$ receptor-mediated postsynaptic currents $(219,220)$. While the first studies disagreed on whether the currents mediated by the chloride channel GABA receptors, excite (219), or inhibit (222) adult mouse GnRH neurons, a recently formed consensus opinion (223) is that the dominant effect of $\mathrm{GABA}_{\mathrm{A}}$ receptor activation is excitation, as also proposed for GABAergic currents in rat GnRH neurons (224). This atypical behavior is due to the absence (or only low expression levels) of the K-Cl co-transporter (KCC2) in GnRH cells (219), an enzyme which normally extrudes chloride from other adult-type neurons. Given that GnRH neuron activity is increased by both GABA and glutamate, these cells need alternative mechanisms for their inhibitory afferent regulation, including retrograde endocannabinoid signaling which inhibits the excitatory GABAergic inputs to GnRH neurons in mice (225).

A recent dual-label immunohistochemical study from our laboratory (51) addressed the relative contributions of GABAergic and glutamatergic afferent neuronal contacts onto the cell bodies and dendrites of human GnRH neurons at the light microscopic level. While an earlier innervation study in the rat used antibodies against glutamic acid decarboxylase to identify GABAergic synaptic afferents to the rat GnRH neurons (217), we detected the GABAergic terminals with a primary antiserum directed against the vesicular inhibitory amino acid transporter (VIAAT) which accumulates GABA (and glycine) into synaptic vesicles.

The results of these studies showed that VIAAT-IR axons establish many axo-somatic and axo-dendritic contacts with human GnRH neurons. The number of such light microscopic appositions was one or two orders of magnitude higher than reported for different peptidergic systems (25), supporting the idea that GABA is also the major neurotransmitter in the afferent regulation of GnRH neurons in the human (51).

\section{Glutamate}

The invariable occurrence of a metabolic glutamate pool in every cell type has made it difficult to immunohistochemically identify excitatory neurons that use glutamate for synaptic communication. In the absence of selective glutamatergic markers, early immunohistochemical work used antibodies against glutamate per se. Such studies provided evidence for IR glutamate in axon terminals that establish asymmetrical synapses with the dendrites, but not the somata, of GnRH-IR neurons in the monkey
(226). The use of specific antisera against the vesicular glutamate transporter isoforms (VGLUT1 and VGLUT2), discovered relatively recently, provided new tools to also distinguish between the two major subclasses of glutamatergic afferents to GnRH neurons. Immuno-electron microscopic studies of rats established that GnRH neurons only receive synapses from the VGLUT2 subclass of glutamatergic neurons and these inputs are most prominent on the dendritic compartment of GnRH cells (227).

In contrast with rodent GnRH neurons, we found that human GnRH neurons were contacted by both VGLUT1-IR and VGLUT2IR fibers, out of which those of the VGLUT2 phenotype were encountered more frequently (51). The combined incidence of these two fibers was somewhat lower on GnRH cell bodies than the incidence of GABAergic contacts, whereas glutamatergic axons (VGLUT1 + VGLUT2) outnumbered GABAergic inputs on GnRH-IR dendrites (51). This glutamatergic dominance is particularly interesting in the light of new information that dendrites are the primary sites of action potential generation in the $\mathrm{GnRH}$ neuron, at least in mice (40).

\section{REGIONAL HETEROGENEITY IN THE AFFERENT REGULATION OF GnRH NEURONS}

As summarized in a review article (25), the incidence of various peptidergic (NPY-, SP-, $\beta$-endorphin-, leu-enkaphalin-, $\mathrm{CRH}-$, and galanin-IR) and catecholaminergic inputs to human GnRH neurons changes region-specifically. The most heavily innervated GnRH subclasses are located in the infundibulum and the median eminence, followed by GnRH neurons in the preoptic area. GnRHIR neurons in the posterior hypothalamus were only innervated occasionally. This differential innervation raises the possibility that the human GnRH neuronal system consists of several functional subclasses (25).

\section{SEXUAL DIMORPHISM AND AGING-DEPENDENT CHANGES IN THE AFFERENT CONTROL OF GnRH NEURONS}

The majority of neuroanatomical studies addressing the innervation of human GnRH neurons only provide qualitative information based on the analysis of a few histological specimens. Difficulties to access human tissue samples in large number, together with the typically high biological, and technical variations among the samples (partly due to different circumstances of life, death, and tissue preservation) are discouraging for quantitative studies using state-of-the-art statistical methods. The most robust biological differences may still be detectable.

Previous quantitative studies of the human KP and NKB systems in our laboratory included histological samples from three adult human models categorized arbitrarily as "young human males" (below 50 years of age), "aged human males" (above 49 years of age), and aged (postmenopausal) women (above 55 years of age). Perikaryon size (labeled IR profile area), regional density of IR cell bodies and neuronal fibers in the Inf, frequency of IR fiber appositions to GnRH-IR neurons, and the colocalization percentages between $\mathrm{KP}$ and $\mathrm{NKB}$ were determined and compared with ANOVA.

SEXUAL DIMORPHISM OF KISSPEPTIN AND NEUROKININ B NEURONS In the absence of hypothalamic tissue samples from premenopausal female subjects, sex differences were only assessed 
between postmenopausal women and aged men (above 49 years) and not between young female and male individuals. Because aged females lack estrogen negative feedback whereas aged males maintain testosterone negative feedback on KP and NKB neurons of the Inf, the sexual dimorphism of these systems might be entirely due to the different sex steroid milieu in the two sexes. Alternatively, females and males may show differences that form under the combined organizational and activational effects of sex steroids. The conceptually important issue of whether or not any sexual dimorphism exists in the human hypothalamus that forms under the organization effects of sex steroids during early development, thus requires clarification.

Larger KP-IR and NKB-IR cell bodies were observed in females than in males (101). The postmenopausal hypertrophy of KP (99) and NKB (98) neurons reported earlier and attributed to the postmenopausal loss of estrogen negative feedback, may partly, or entirely explain these sex differences. KP neurons also showed other robust sex differences in that the number of KP-IR somata, the density of KP-IR fibers and the incidence of afferent contacts they formed on GnRH neurons were much higher in aged women compared with aged men. These differences, together, indicate a robust aging-related expansion of the KP neuronal system and a largely enhanced excitatory KP tone on GnRH neurons of postmenopausal women compared with elderly men.

The regional density of NKB cell bodies was also significantly higher in women compared with men, but there was no significant sex dimorphism in the regional density of NKB fibers and the incidence of their appositions to GnRH-IR cells (101). A further interesting sex difference occurred in the overlap between KP-IR and NKB-IR inputs to GnRH neurons; immunofluorescent studies identified a higher percentage of NKB-IR afferents with $\mathrm{KP}$ in women $(31 \%)$ compared with men $(9 \%)$. The percentage of KP-IR contacts co-containing NKB was also higher in females (26\%) vs. males (10\%). A different immunohistochemical study (228) identified additional aspects of a sexual dimorphism of the human NKB system. The NKB-IR innervation of the Inf in this study was higher in adult females compared with males, whereas the pars tuberalis received a dense NKB-IR innervation in adult males but not in females (228). In addition, the volume occupied by NKB immunoreactivity in the Inf of adult men was significantly lower compared with adult women and with adult male-to-female transsexuals (228).

\section{AGING-DEPENDENT CHANGES OF THE KISSPEPTIN AND NEUROKININ B SYSTEMS IN MEN}

Aging-related decline in reproductive functions is less dramatic in men than in women because of the sustained testosterone production by the testes (229), although the negative feedback response of the reproductive axis to testosterone shows a declining trend with aging (230). Clinical symptoms of late-onset hypogonadism in elderly men include decreased morning erections, erectile dysfunction, and decreased frequency of sexual thoughts (231). Based on animal experiments, KP and NKB neurons play an important role in testosterone negative feedback to the male hypothalamus $(165,174)$. From this, we anticipated enhanced central KP- and NKB-signaling in the Inf of aged vs. young men. We have carried out quantitative immunohistochemical studies on a relatively large number $(N=20)$ of hypothalamic samples from adult men (49) and analyzed the same immunohistochemical parameters that showed sexual dimorphism in aged subjects.

This study identified robust aging-dependent enhancements in the regional densities of KP-IR perikarya and fibers, and in the incidence of contacts they established with the cell bodies and dendrites of GnRH neurons (49). The number of NKB-IR perikarya, the density of NKB-IR fibers and the incidences of axonal appositions to $\mathrm{GnRH}$ neurons also increased with age, but to lesser extent than in case of KP (49). In addition, in dual-immunofluorescent studies, the incidence of NKB-IR perikarya that co-contained KP increased from $36 \%$ in young to $68 \%$ in aged men, indicating that a higher proportion of NKB neurons express detectable levels of KP in aged individuals (49). Finally, we identified a mild but statistically significant hypertrophy of KP-IR and NKB-IR neurons. The magnitude of the increase was reminiscent to the hypertrophy of unidentified neurons in the Inf of aged men (232). It requires clarification if the increased incidences of KP-IR and NKB-IR contacts on GnRH neurons in aged male individuals (49) reflect increased numbers of synapses or alternatively, enhanced detectability of KP-IR and NKB-IR fibers. The first possibility gains support from the electron microscopic observation on male rat that the number of axo-somatic synapses to GnRH neurons increases about threefold by middle age and 10 -fold by old age (233).

\section{IMPORTANT REMAINING ISSUES}

Morphological studies of post mortem human hypothalami will remain valuable tools to address further important questions unanswered so far. The aims of such studies will include:

1. Identification of $\mathrm{GnRH}$ neuron subpopulations based on anatomical criteria.

2. 3-D reconstruction of the GnRH neuron with its dendritic arbor.

3. Identification and subcellular localization of neuropeptide receptors (KISS1R; NK3, etc.) in GnRH neurons.

4. Characterization of neuroanatomical changes in the GnRH network in association with pubertal transition.

5. Identification of anatomical changes in the GnRH network accompanying reproductive aging.

6. Anatomical and neurochemical characterization of the two human KP cell populations.

7. Further analysis of sex steroid feedback sites, including the Inf and the putative human "AVPV" ("RP3V"), and characterization of steroid target cells.

8. Clear distinction of possible organizational sex steroid effects that may contribute to the sexual dimorphism of the human KP neuronal network.

9. Localization of steroid hormone receptors in human KP neurons.

10. Identification of new hypothalamic and extrahypothalamic target cells to KP neurons.

11. Characterization of the afferent connectivity of KP neurons.

12. Identification and characterization of new players in the pulse generator. 


\section{REFERENCES}

1. Carmel PW, Araki S, Ferin M. Pituitary stalk portal blood collection in rhesus monkeys: evidence for pulsatile release of gonadotropinreleasing hormone ( $\mathrm{GnRH})$. Endocrinology (1976) 99(1):243-8. doi:10.1210/endo-99-1-243

2. Clarke IJ, Cummins JT. The temporal relationship between gonadotropin releasing hormone (GnRH) and luteinizing hormone (LH) secretion in ovariectomized ewes. Endocrinology (1982) 111(5):1737-9. doi:10.1210/endo-111-5-1737

3. Belchetz PE, Plant TM, Nakai Y, Keogh EJ, Knobil E. Hypophysial responses to continuous and intermittent delivery of hypothalamic gonadotropin-releasing hormone. Science (1978) 202(4368):631-3. doi:10.1126/science. 100883

4. Wray S. Development of luteinizing hormone releasing hormone neurones. $J$ Neuroendocrinol (2001) 13(1):3-11. doi:10.1046/j. 1365-2826.2001.00609.x

5. Schwanzel-Fukuda M, Pfaff DW. Origin of luteinizing hormonereleasing hormone neurons. Nature (1989) 338(6211):161-4. doi:10.1038/338161a0

6. Schwanzel-Fukuda M, Bick D, Pfaff DW. Luteinizing hormonereleasing hormone (LHRH)expressing cells do not migrate normally in an inherited hypogonadal (Kallmann) syndrome. Brain Res Mol Brain Res (1989) 6(4):311-26. doi:10.1016/0169328X(89)90076-4

7. Merchenthaler I, Kovacs G, Lavasz G, Setalo G. The preopticoinfundibular LH-RH tract of the rat. Brain Res (1980) 198(1):63-74. doi:10.1016/00068993(80)90344-3

8. Setalo G, Vigh S, Schally AV, Arimura A, Flerko B. Immunohistological study of the origin of LH-RH-containing nerve fibers of the rat hypothalamus. Brain Res (1976) 103(3):597-602. doi: 10.1016/0006-8993(76)90462-5

9. Lehman MN, Robinson JE, Karsch FJ, Silverman AJ. Immunocytochemical localization of luteinizing hormone-releasing hormone (LHRH) pathways in the sheep brain during anestrus and the mid-luteal phase of the estrous cycle. J Comp Neurol (1986) 244(1):19-35. doi:10.1002/cne.902440103

10. Silverman AJ. Distribution of luteinizing hormone-releasing hormone (LHRH) in the guinea pig brain. Endocrinology (1976) 99(1):30-41. doi:10.1210/endo-99-1-30

11. King JC, Anthony EL. LHRH neurons and their projections in humans and other mammals: species comparisons. Peptides (1984) 5(Suppl 1):195-207. doi: 10.1016/0196-9781(84)90277-8

12. Rance NE, Young WS III, McMullen NT. Topography of neurons expressing luteinizing hormone-releasing hormone gene transcripts in the human hypothalamus and basal forebrain. J Comp Neurol (1994) 339(4):573-86. doi:10.1002/cne.903390408

13. Barry J. Characterization and topography of LH-RH neurons in the human brain. Neurosci Lett (1976) 3(5-6):287-91. doi:10. 1016/0304-3940(76)90056-2

14. Stopa EG, Koh ET, Svendsen CN, Rogers WT, Schwaber JS, King JC. Computer-assisted mapping of immunoreactive mammalian gonadotropin-releasing hormone in adult human basal forebrain and amygdala. Endocrinology (1991) 128(6):3199-207. doi: 10.1210/endo-128-6-3199

15. Dudas B, Mihaly A, Merchenthaler I. Topography and associations of luteinizing hormone-releasing hormone and neuropeptide Y-immunoreactive neuronal systems in the human diencephalon. J Comp Neurol (2000) 427(4):593-603. doi:10.1002/ 1096-9861(20001127)427:4<593: :AID-CNE7>3.0.CO;2-C

16. Barry J. Immunofluorescence study of LRF neurons in man. Cell Tissue Res (1977) 181(1):1-14. doi:10.1007/BF00222770

17. Silverman AJ, Krey LC, Zimmerman EA. A comparative study of the luteinizing hormone releasing hormone (LHRH) neuronal networks in mammals. Biol Reprod (1979) 20(1):98-110.

18. Song T, Nikolics K, Seeburg $\mathrm{PH}$, Goldsmith PC. GnRHprohormone-containing neurons in the primate brain: immunostaining for the GnRHassociated peptide. Peptides (1987) 8(2):335-46. doi:10.1016/01969781(87)90109-4

19. Abe J, Okamura H, Ibata Y, Motoyama A, Wakabayashi I, Ling $\mathrm{N}$, et al. Immunocytochemical demonstration of GAPlike immunoreactive neuronal elements in the human hypothalamus and pituitary. Histochemistry (1990) 94(2):127-33. doi:10.1007/ BF02440178
20. Bloch B, Gaillard RC, Culler MD, Negro-Vilar A. Immunohistochemical detection of proluteinizing hormone-releasing hormone peptides in neurons in the human hypothalamus. J Clin Endocrinol Metab (1992) 74(1):135-8. doi:10.1210/jc.74.1.135

21. Paulin C, Dubois MP, Barry J, Dubois PM. Immunofluorescence study of LH-RH producing cells in the human fetal hypothalamus. Cell Tissue Res (1977) 182(3):341-5. doi:10.1007/ BF00219769

22. Anthony EL, King JC, Stopa EG. Immunocytochemical localization of LHRH in the median eminence, infundibular stalk, and neurohypophysis. Evidence for multiple sites of releasing hormone secretion in humans and other mammals. Cell Tissue Res (1984) 236(1):5-14. doi:10.1007/ BF00216506

23. King JC, Anthony EL, Fitzgerald DM, Stopa EG. Luteinizing hormone-releasing hormone neurons in human preoptic/hypothalamus: differential intraneuronal localization of immunoreactive forms. $J$ Clin Endocrinol Metab (1985) 60(1):88-97. doi:10.1210/jcem-60-1-88

24. Najimi M, Chigr F, Jordan D, Leduque $\mathrm{P}$, Bloch B, Tommasi $\mathrm{M}$, et al. Anatomical distribution of LHRH-immunoreactive neurons in the human infant hypothalamus and extrahypothalamic regions. Brain Res (1990) 516(2):280-91. doi:10.1016/00068993(90)90929-6

25. Dudas B, Merchenthaler I. Threedimensional representation of the neurotransmitter systems of the human hypothalamus: inputs of the gonadotrophin hormonereleasing hormone neuronal system. J Neuroendocrinol (2006) 18(2):79-95. doi:10.1111/j.13652826.2005.01398.x

26. Campbell RE, Han SK, Herbison AE. Biocytin filling of adult gonadotropin-releasing hormone neurons in situ reveals extensive, spiny, dendritic processes. Endocrinology (2005) 146(3):1163-9. doi:10.1210/en.2004-1369

27. Duvernoy H, Koritke JG, Monnier G. Vascularization of the posterior tuber in man and its relation to the tuber-hypophyseal vasculature. J Neurovisc Relat (1971) 32(2):112-42. doi:10.1007/ BF02310044
28. Hrabovszky E, Sipos MT, Molnar CS, Ciofi P, Borsay BA, Gergely $P$, et al. Low degree of overlap between kisspeptin, neurokinin $\mathrm{B}$, and dynorphin immunoreactivities in the infundibular nucleus of young male human subjects challenges the KNDy neuron concept. Endocrinology (2012) 153(10):4978-89. doi:10.1210/en. 2012- 1545

29. Barry J. Septo-epithalamohabenular LRF-reactive neurons in monkeys. Brain Res (1978) 151(1):183-7. doi:10.1016/00068993(78)90962-9

30. Silverman AJ, Antunes JL, Abrams GM, Nilaver G, Thau R, Robinson JA, et al. The luteinizing hormone-releasing hormone pathways in rhesus (Macaca mulatta) and pigtailed (Macaca nemestrina) monkeys: new observations on thick, unembedded sections. J Comp Neurol (1982) 211(3):309-17. doi:10.1002/cne. 902110309

31. Barry J, Carette B. Immunofluorescence study of LRF neurons in primates. Cell Tissue Res (1975) 164(2):163-78. doi:10. 1007/BF00218971

32. Leranth C, Segura LM, Palkovits M, MacLusky NJ, Shanabrough M, Naftolin F. The LH-RH-containing neuronal network in the preoptic area of the rat: demonstration of LH-RH-containing nerve terminals in synaptic contact with LH-RH neurons. Brain Res (1985) 345(2):332-6. doi:10.1016/00068993(85)91011-X

33. Chen WP, Witkin JW, Silverman AJ. Beta-endorphin and gonadotropin-releasing hormone synaptic input to gonadotropinreleasing hormone neurosecretory cells in the male rat. J Comp Neurol (1989) 286(1):85-95. doi:10.1002/ cne. 902860106

34. Thind KK, Goldsmith PC. Infundibular gonadotropinreleasing hormone neurons are inhibited by direct opioid and autoregulatory synapses in juvenile monkeys. Neuroendocrinology (1988) 47(3):203-16. doi:10.1159/000124914

35. Vazquez-Martinez R, Shorte SL, Boockfor FR, Frawley LS. Synchronized exocytotic bursts from gonadotropin-releasing hormoneexpressing cells: dual control by intrinsic cellular pulsatility and gap junctional communication. Endocrinology (2001) 142(5):2095-101. doi:10.1210/en. 142.5 .2095 
36. Witkin JW, O'Sullivan H, Silverman AJ. Novel associations among gonadotropin-releasing hormone neurons. Endocrinology (1995) 136(10):4323-30. doi:10.1210/en. 136.10 .4323

37. Campbell RE, Suter KJ. Redefining the gonadotrophin-releasing hormone neurone dendrite. $\mathrm{J} \mathrm{Neu}$ roendocrinol (2010) 22(7):650-8. doi:10.1111/j.1365-2826.2010. 02032.x

38. Campbell RE, Gaidamaka G, Han SK, Herbison AE. Dendro-dendritic bundling and shared synapses between gonadotropin-releasing hormone neurons. Proc Natl Acad Sci U $S$ A (2009) 106(26):10835-40. doi:10.1073/pnas.0903463106

39. Herde MK, Geist K, Campbell RE, Herbison AE. Gonadotropinreleasing hormone neurons extend complex highly branched dendritic trees outside the blood-brain barrier. Endocrinology (2011) 152(10):3832-41. doi:10.1210/en.2011-1228

40. Roberts CB, Campbell RE, Herbison AE, Suter KJ. Dendritic action potential initiation in hypothalamic gonadotropin-releasing hormone neurons. Endocrinology (2008) 149(7):3355-60. doi:10. 1210/en.2008-0152

41. Rasmussen DD, Gambacciani M, Swartz W, Tueros VS, Yen SS. Pulsatile gonadotropinreleasing hormone release from the human mediobasal hypothalamus in vitro: opiate receptormediated suppression. Neuroendocrinology (1989) 49(2):150-6. doi:10.1159/000125107

42. Navarro VM, Gottsch ML, Chavkin C, Okamura H, Clifton DK, Steiner RA. Regulation of gonadotropinreleasing hormone secretion by kisspeptin/dynorphin/neurokinin $B$ neurons in the arcuate nucleus of the mouse. J Neurosci (2009) 29(38):11859-66. doi:10.1523/ JNEUROSCI.1569-09.2009

43. Wakabayashi Y, Nakada T, Murata K, Ohkura S, Mogi K, Navarro VM, et al. Neurokinin B and dynorphin A in kisspeptin neurons of the arcuate nucleus participate in generation of periodic oscillation of neural activity driving pulsatile gonadotropin-releasing hormone secretion in the goat. $\mathrm{J} \mathrm{Neu}$ rosci (2010) 30(8):3124-32. doi: 10. 1523/JNEUROSCI.5848-09.2010

44. Ohkura S, Takase K, Matsuyama S, Mogi K, Ichimaru T, Wakabayashi $\mathrm{Y}$, et al. Gonadotrophin-releasing hormone pulse generator activity in the hypothalamus of the goat. J Neuroendocrinol (2009) 21(10):813-21. doi:10.1111/j. 1365-2826.2009.01909.x

45. Hrabovszky E, Borsay BA, Racz K, Herczeg L, Ciofi P, Bloom SR, et al. Substance $\mathrm{p}$ immunoreactivity exhibits frequent colocalization with kisspeptin and neurokinin B in the human infundibular region. PLoS ONE (2013) 8(8):e72369. doi:10.1371/journal. pone.0072369

46. Witkin JW, Silverman AJ. Synaptology of luteinizing hormonereleasing hormone neurons in rat preoptic area. Peptides (1985) 6(2):263-71. doi:10.1016/01969781(85)90050-6

47. Witkin JW, Ferin M, Popilskis SJ, Silverman AJ. Effects of gonadal steroids on the ultrastructure of GnRH neurons in the rhesus monkey: synaptic input and glial apposition. Endocrinology (1991) 129(2):1083-92. doi: 10.1210/endo-129-2-1083

48. Fekete CS, Strutton PH, Cagampang FR, Hrabovszky E, Kallo I, Shughrue PJ, et al. Estrogen receptor immunoreactivity is present in the majority of central histaminergic neurons: evidence for a new neuroendocrine pathway associated with luteinizing hormone-releasing hormonesynthesizing neurons in rats and humans. Endocrinology (1999) 140(9):4335-41. doi:10.1210/en. 140.9.4335

49. Molnar CS, Vida B, Sipos MT, Ciofi P, Borsay BA, Racz K, et al. Morphological evidence for enhanced kisspeptin and neurokinin B signaling in the infundibular nucleus of the aging man. Endocrinology (2012) 153(11):5428-39. doi:10. 1210/en.2012-1739

50. Dudas B, Merchenthaler I. Close juxtapositions between LHRH immunoreactive neurons and substance $\mathrm{P}$ immunoreactive axons in the human diencephalon. $J$ Clin Endocrinol Metab (2002) 87(6):2946-53. doi:10.1210/jc.2002-020996

51. Hrabovszky E, Molnar CS, Nagy R, Vida B, Borsay BA, Racz $\mathrm{K}$, et al. Glutamatergic and GABAergic innervation of human gonadotropin-releasing hormoneI neurons. Endocrinology (2012) 153(6):2766-76. doi:10.1210/en. 2011-2106

52. Fiala JC, Spacek J, Harris KM. Dendritic spine pathology: cause or consequence of neurological disorders? Brain Res Brain Res Rev
(2002) 39(1):29-54. doi:10.1016/ S0165-0173(02)00158-3

53. Ciofi P, Leroy D, Tramu G. Sexual dimorphism in the organization of the rat hypothalamic infundibular area. Neuroscience (2006) 141(4):1731-45. doi:10. 1016/j.neuroscience.2006.05.041

54. Kawakami SI, Hirunagi K, Ichikawa $\mathrm{M}$, Tsukamura $\mathrm{H}$, Maeda KI. Evidence for terminal regulation of $\mathrm{GnRH}$ release by excitatory amino acids in the median eminence in female rats: a dual immunoelectron microscopic study. Endocrinology (1998) 139(3):1458-61. doi:10.1210/en.139.3.1458

55. Lin W, McKinney K, Liu L, Lakhlani S, Jennes L. Distribution of vesicular glutamate transporter-2 messenger ribonucleic Acid and protein in the septum-hypothalamus of the rat. Endocrinology (2003) 144(2):662-70. doi:10.1210/en.2002-220908

56. Kawakami S, Ichikawa M, Murahashi K, Hirunagi K, Tsukamura H, Maeda K. Excitatory amino acids act on the median eminence nerve terminals to induce gonadotropin-releasing hormone release in female rats. Gen Comp Endocrinol (1998) 112(3):372-82. doi:10.1006/gcen.1998.7140

57. Krajewski SJ, Anderson MJ Iles-Shih L, Chen KJ, Urbanski HF, Rance NE. Morphologic evidence that neurokinin B modulates gonadotropin-releasing hormone secretion via neurokinin 3 receptors in the rat median eminence. $J$ Comp Neurol (2005) 489(3):372-86. doi:10.1002/cne.20626

58. Matsuyama S, Ohkura S, Mogi K, Wakabayashi Y, Mori Y, Tsukamura $\mathrm{H}$, et al. Morphological evidence for direct interaction between kisspeptin and gonadotropin-releasing hormone neurons at the median eminence of the male goat: an immunoelectron microscopic study. Neuroendocrinology (2011) 94(4):323-32. doi:10.1159/000331576

59. Ramaswamy S, Guerriero KA, Gibbs RB, Plant TM. Structural interactions between kisspeptin and GnRH neurons in the mediobasal hypothalamus of the male rhesus monkey (Macaca mulatta) as revealed by double immunofluorescence and confocal microscopy. Endocrinology (2008) 149(9):4387-95. doi:10.1210/en.2008-0438
60. Hrabovszky E, Ciofi P, Vida B, Horvath MC, Keller E, Caraty A, et al. The kisspeptin system of the human hypothalamus: sexual dimorphism and relationship with gonadotropin-releasing hormone and neurokinin B neurons. Eur J Neurosci (2010) 31(11):1984-98. doi:10.1111/j.1460-9568.2010. 07239.x

61. d'Anglemont de Tassigny $X$, Fagg LA, Carlton MB, Colledge WH. Kisspeptin can stimulate gonadotropin-releasing hormone $(\mathrm{GnRH})$ release by a direct action at $\mathrm{GnRH}$ nerve terminals. Endocrinology (2008) 149(8):3926-32. doi:10.1210/en.2007-1487

62. Keen KL, Wegner FH, Bloom SR, Ghatei MA, Terasawa E. An increase in kisspeptin-54 release occurs with the pubertal increase in luteinizing hormone-releasing hormone-1 release in the stalkmedian eminence of female rhesus monkeys in vivo. Endocrinology (2008) 149(8):4151-7. doi:10. 1210/en.2008-0231

63. Matsui H, Takatsu Y, Kumano S, Matsumoto H, Ohtaki T. Peripheral administration of metastin induces marked gonadotropin release and ovulation in the rat. Biochem Biophys Res Commun (2004) 320(2):383-8. doi:10.1016/j.bbrc.2004.05.185

64. Navarro VM, Castellano JM, Fernandez-Fernandez R, Tovar S, Roa J, Mayen A, et al. Effects of KiSS-1 peptide, the natural ligand of GPR54, on follicle-stimulating hormone secretion in the rat. Endocrinology (2005) 146(4):1689-97. doi:10.1210/en.2004-1353

65. Shahab M, Mastronardi C, Seminara SB, Crowley WF, Ojeda SR, Plant TM. Increased hypothalamic GPR54 signaling: a potential mechanism for initiation of puberty in primates. Proc Natl Acad Sci U $S$ A (2005) 102(6):2129-34. doi:10.1073/pnas.0409822102

66. Dhillo WS, Chaudhri OB, Patterson M, Thompson EL, Murphy $\mathrm{KG}$, Badman MK, et al. Kisspeptin54 stimulates the hypothalamicpituitary gonadal axis in human males. J Clin Endocrinol Metab (2005) 90(12):6609-15. doi:10. 1210/jc.2005- 1468

67. Dhillo WS, Chaudhri OB, Thompson EL, Murphy KG, Patterson M, Ramachandran $\mathrm{R}$, et al. Kisspeptin-54 stimulates gonadotropin release most 
potently during the preovulatory phase of the menstrual cycle in women. $J$ Clin Endocrinol Metab (2007) 92(10):3958-66. doi:10.1210/jc.2007-1116

68. Dudas B, Merchenthaler I. Bidirectional associations between galanin and luteinizing hormonereleasing hormone neuronal systems in the human diencephalon. Neuroscience (2004) 127(3):695-707. doi:10.1016/j. neuroscience.2004.05.018

69. Tobet SA, Chickering TW, King JC, Stopa EG, Kim K, KuoLeblank V, et al. Expression of gamma-aminobutyric acid and gonadotropin-releasing hormone during neuronal migration through the olfactory system. Endocrinology (1996) 137(12):5415-20. doi:10.1210/en.137.12.5415

70. Hrabovszky E, Turi GF, Kallo I, Liposits Z. Expression of vesicular glutamate transporter2 in gonadotropin-releasing hormone neurons of the adult male rat. Endocrinology (2004) 145(9):4018-21. doi:10.1210/en. 2004-0589

71. Merchenthaler I, Lopez FJ, NegroVilar A. Colocalization of galanin and luteinizing hormone-releasing hormone in a subset of preoptic hypothalamic neurons: anatomical and functional correlates. Proc Natl Acad Sci U S A (1990) 87(16):6326-30. doi:10. 1073/pnas.87.16.6326

72. Coen CW, Montagnese C, Opacka-Juffry J. Coexistence of gonadotrophin-releasing hormone and galanin: immunohistochemical and functional studies. J Neuroendocrinol (1990) 2(2):107-11. doi:10.1111/j.13652826.1990.tb00839.x

73. Rajendren G, Gibson MJ. Expression of galanin immunoreactivity in gonadotropin-releasing hormone neurons in mice: a confocal microscopic study. Brain Res (1999) 821(2):270-6. doi:10.1016/ S0006-8993(99)01059-8

74. Dufourny L, Schofield N, Skinner DC. Immunoreactive galanin expression in ovine gonadotropinreleasing hormone neurones: no effects of gender or reproductive status. J Neuroendocrinol (2003) 15(11):1062-9. doi:10.1046/j. 1365-2826.2003.01098.x

75. Merchenthaler I, Lennard DE, Lopez FJ, Negro-Vilar A. Neonatal imprinting predetermines the sexually dimorphic, estrogendependent expression of galanin in luteinizing hormone-releasing hormone neurons. Proc Natl Acad Sci U S A (1993) 90(22):10479-83. doi:10.1073/pnas.90.22.10479

76. Ohtsuka S, Nishizaki T, Tasaka K, Miyake A, Tanizawa O, Yamatodani A, et al. Estrogen stimulates gonadotropin-releasing hormone release from rat hypothalamus independently through catecholamine and histamine in vitro. Acta Endocrinol (1989) 120(5):644-8.

77. Ciofi P. Phenotypical segregation among female rat hypothalamic gonadotropin-releasing hormone neurons as revealed by the sexually dimorphic coexpression of cholecystokinin and neurotensin. Neuroscience (2000) 99(1):133-47. doi: 10.1016/S0306-4522(00)00186-X

78. Herbison AE. Multimodal influence of estrogen upon gonadotropin-releasing hormone neurons. Endocr Rev (1998) 19(3):302-30. doi:10.1210/er.19.3.302

79. Shivers BD, Harlan RE, Morrell JI, Pfaff DW. Absence of oestradiol concentration in cell nuclei of LHRH-immunoreactive neurones. Nature (1983) 304(5924):345-7. doi:10.1038/304345a0

80. Watson RE Jr, Langub MC Jr, Landis JW. Further evidence that most luteinizing hormonereleasing hormone neurons are not directly estrogen-responsive: simultaneous localization of luteinizing hormone-releasing hormone and estrogen receptor immunoreactivity in the guineapig brain. $J$ Neuroendocrinol (1992) 4(3):311-7. doi:10.1111/j. 1365-2826.1992.tb00173.x

81. Herbison AE, Theodosis DT. Localization of oestrogen receptors in preoptic neurons containing neurotensin but not tyrosine hydroxylase, cholecystokinin or luteinizing hormone-releasing hormone in the male and female rat. Neuroscience (1992) 50(2):283-98. doi:10.1016/03064522(92)90423-Y

82. Kuiper GG, Enmark E, PeltoHuikko M, Nilsson S, Gustafsson JA. Cloning of a novel receptor expressed in rat prostate and ovary. Proc Natl Acad Sci U S A (1996) 93(12):5925-30. doi:10. 1073/pnas.93.12.5925

83. Hrabovszky E, Shughrue PJ, Merchenthaler I, Hajszan T, Carpenter CD, Liposits Z, et al. Detection of estrogen receptorbeta messenger ribonucleic acid and 125I-estrogen binding sites in luteinizing hormonereleasing hormone neurons of the rat brain. Endocrinology (2000) 141(9):3506-9. doi:10.1210/en.141.9.3506

84. Skynner MJ, Sim JA, Herbison AE. Detection of estrogen receptor alpha and beta messenger ribonucleic acids in adult gonadotropin-releasing hormone neurons. Endocrinology (1999) 140(11):5195-201. doi:10.1210/en.140.11.5195

85. Hrabovszky E, Steinhauser A, Barabas K, Shughrue PJ, Petersen SL, Merchenthaler I, et al. Estrogen receptor-beta immunoreactivity in luteinizing hormone-releasing hormone neurons of the rat brain. Endocrinology (2001) 142(7):3261-4. doi:10.1210/en.142.7.3261

86. Kallo I, Butler JA, BarkovicsKallo M, Goubillon ML Coen CW. Oestrogen receptor beta-immunoreactivity in gonadotropin releasing hormoneexpressing neurones: regulation by oestrogen. $J$ Neuroendocrinol (2001) 13(9):741-8. doi:10.1046/j. 1365-2826.2001.00708.x

87. Herbison AE, Pape JR. New evidence for estrogen receptors in gonadotropin-releasing hormone neurons. Front Neuroendocrinol (2001) 22(4):292-308. doi:10.1006/frne.2001.0219

88. Skinner DC, Dufourny L. Oestrogen receptor beta-immunoreactive neurones in the ovine hypothalamus: distribution and colocalisation with gonadotropin-releasing hormone. $J$ Neuroendocrinol (2005) 17(1):29-39. doi:10.1111/j. 1365-2826.2005.01271.x

89. Herbison AE, Robinson JE, Skinner DC. Distribution of estrogen receptor-immunoreactive cells in the preoptic area of the ewe: co-localization with glutamic acid decarboxylase but not luteinizing hormonereleasing hormone. Neuroendocrinology (1993) 57(4):751-9. doi:10.1159/000126433

90. Hrabovszky E, Kallo I, Szlavik N, Keller E, Merchenthaler I, Liposits Z. Gonadotropin-releasing hormone neurons express estrogen receptor-beta. J Clin Endocrinol Metab (2007) 92(7):2827-30. doi: 10.1210/jc.2006-2819

91. Cheong RY, Kwakowsky A, Barad Z, Porteous R, Herbison AE, Abraham IM. Estradiol acts directly and indirectly on multiple signaling pathways to phosphorylate cAMPresponse element binding protein in GnRH neurons. Endocrinology (2012) 153(8):3792-803. doi:10. 1210/en.2012-1232

92. Abraham IM, Han SK, Todman MG, Korach KS, Herbison AE. Estrogen receptor beta mediates rapid estrogen actions on gonadotropin-releasing hormone neurons in vivo. J Neurosci (2003) 23(13):5771-7.

93. Temple JL, Laing E, Sunder A, Wray S. Direct action of estradiol on gonadotropin-releasing hormone-1 neuronal activity via a transcription-dependent mechanism. J Neurosci (2004) 24(28):6326-33. doi:10.1523/ JNEUROSCI.1006-04.2004

94. Pak TR, Chung WC, Roberts JL, Handa RJ. Ligand-independent effects of estrogen receptor beta on mouse gonadotropinreleasing hormone promoter activity. Endocrinology (2006) 147(4):1924-31. doi:10.1210/en.2005-1297

95. Merchenthaler I, Hoffman GE, Lane MV. Estrogen and estrogen receptor-\{beta $\} \quad(\mathrm{ER}\{$ beta $\}$ )selective ligands induce galanin expression within gonadotropin hormone-releasing hormoneimmunoreactive neurons in the female rat brain. Endocrinology (2005) 146(6):2760-5. doi:10.1210/en.2004-1562

96. Christian CA, Glidewell-Kenney C, Jameson JL, Moenter SM. Classical estrogen receptor alpha signaling mediates negative and positive feedback on gonadotropin-releasing hormone neuron firing. Endocrinology (2008) 149(11):5328-34. doi:10.1210/en.2008-0520

97. Quaynor SD, Stradtman EW Jr, Kim HG, Shen Y, Chorich LP, Schreihofer DA, et al. Delayed puberty and estrogen resistance in a woman with estrogen receptor alpha variant. $N$ Engl J Med (2013) 369(2):164-71. doi:10. 1056/NEJMoal303611

98. Rance NE, Young WS III. Hypertrophy and increased gene expression of neurons containing neurokinin-B and substance-P messenger ribonucleic acids in the hypothalami of postmenopausal women. Endocrinology (1991) 128(5):2239-47. doi:10.1210/endo-128-5-2239

99. Rometo AM, Krajewski SJ, Voytko ML, Rance NE. Hypertrophy and increased kisspeptin gene expression in the hypothalamic infundibular nucleus of postmenopausal 
women and ovariectomized monkeys. J Clin Endocrinol Metab (2007) 92(7):2744-50. doi:10.1210/jc.2007-0553

100. Rometo AM, Rance NE. Changes in prodynorphin gene expression and neuronal morphology in the hypothalamus of postmenopausal women. J Neuroendocrinol (2008) 20(12):1376-81. doi:10.1111/j. 1365-2826.2008.01796.x

101. Hrabovszky E, Molnar CS, Sipos MT, Vida B, Ciofi P, Borsay BA, et al. Sexual dimorphism of kisspeptin and neurokinin $\mathrm{B}$ immunoreactive neurons in the infundibular nucleus of aged men and women. Front Endocrinol (Lausanne) (2011) 2:80. doi:10. 3389/fendo.2011.00080

102. Mittelman-Smith MA, Williams H, Krajewski-Hall SJ, Lai J, Ciofi P, McMullen NT, et al. Arcuate kisspeptin/neurokinin B/dynorphin (KNDy) neurons mediate the estrogen suppression of gonadotropin secretion and body weight. Endocrinology (2012) 153(6):2800-12. doi:10.1210/en.2012-1045

103. Mittelman-Smith MA, Williams H, Krajewski-Hall SJ, McMullen NT, Rance NE. Role for kisspeptin/neurokinin $\mathrm{B} /$ dynorphin (KNDy) neurons in cutaneous vasodilatation and the estrogen modulation of body temperature. Proc Natl Acad Sci U S A (2012) 109(48):19846-51. doi:10.1073/pnas.1211517109

104. Mai J, Assheuer J, Paxinos G editors. Atlas of the Human Brain. San Diego: Academic Press (1997).

105. Krey LC, Butler WR, Knobil E. Surgical disconnection of the medial basal hypothalamus and pituitary function in the rhesus monkey. I. Gonadotropin secretion. Endocrinology (1975) 96(5):1073-87. doi:10.1210/endo96-5-1088

106. Hess DL, Wilkins RH, Moossy J, Chang JL, Plant TM, McCormack JT, et al. Estrogen-induced gonadotropin surges in decerebrated female rhesus monkeys with medial basal hypothalamic peninsulae. Endocrinology (1977) 101(4):1264-71. doi:10.1210/endo-101-4-1264

107. Knobil E. The neuroendocrine control of the menstrual cycle. Recent Prog Horm Res (1980) 36:53-88.

108. Parker SL, Kalra SP, Crowley WR. Neuropeptide Y modulates the binding of a gonadotropinreleasing hormone $(\mathrm{GnRH})$ analog to anterior pituitary GnRH receptor sites. Endocrinology (1991) 128(5):2309-16. doi:10.1210/endo-128-5-2309

109. Crowley WR, Kalra SP. Neuropeptide $\mathrm{Y}$ stimulates the release of luteinizing hormone-releasing hormone from medial basal hypothalamus in vitro: modulation by ovarian hormones. Neuroendocrinology (1987) 46(2):97-103. doi:10.1159/000124804

110. Woller MJ, Terasawa E. Infusion of neuropeptide $\mathrm{Y}$ into the stalk-median eminence stimulates in vivo release of luteinizing hormone-release hormone in gonadectomized rhesus monkeys. Endocrinology (1991) 128(2):1144-50. doi:10.1210/endo-128-2-1144

111. Tsuruo Y, Kawano H, Kagotani Y, Hisano S, Daikoku S, Chihara K, et al. Morphological evidence for neuronal regulation of luteinizing hormone-releasing hormone-containing neurons by neuropeptide $\mathrm{Y}$ in the rat septopreoptic area. Neurosci Lett (1990) 110(3):261-6. doi:10.1016/03043940(90)90857-6

112. Li C, Chen P, Smith MS. Morphological evidence for direct interaction between arcuate nucleus neuropeptide Y (NPY) neurons and gonadotropin-releasing hormone neurons and the possible involvement of NPY Y1 receptors. Endocrinology (1999) 140(11):5382-90. doi:10.1210/en. 140.11 .5382

113. Campbell RE, ffrench-Mullen JM, Cowley MA, Smith MS, Grove KL. Hypothalamic circuitry of neuropeptide $\mathrm{Y}$ regulation of neuroendocrine function and food intake via the Y5 receptor subtype. Neuroendocrinology (2001) 74(2):106-19. doi:10.1159/000054676

114. Simonian SX, Spratt DP, Herbison AE. Identification and characterization of estrogen receptor alpha-containing neurons projecting to the vicinity of the gonadotropin-releasing hormone perikarya in the rostral preoptic area of the rat. J Comp Neurol (1999) 411(2):346-58. doi:10.1002/ (SICI)1096-9861(19990823)411: 2<346::AID-CNE13>3.0.CO;2-S

115. Turi GF, Liposits Z, Moenter SM, Fekete C, Hrabovszky E. Origin of neuropeptide Y-containing afferents to gonadotropinreleasing hormone neurons in male mice. Endocrinology
(2003) 144(11):4967-74. doi:10.1210/en.2003-0470

116. Broberger C, Johansen J, Johansson C, Schalling M, Hokfelt T. The neuropeptide Y/agouti generelated protein (AGRP) brain circuitry in normal, anorectic, and monosodium glutamatetreated mice. Proc Natl Acad Sci U S A (1998) 95(25):15043-8. doi:10.1073/pnas.95.25.15043

117. Sawchenko PE, Swanson LW, Grzanna R, Howe PR, Bloom SR, Polak JM. Colocalization of neuropeptide $\mathrm{Y}$ immunoreactivity in brainstem catecholaminergic neurons that project to the paraventricular nucleus of the hypothalamus. J Comp Neurol (1985) 241(2):138-53. doi:10. 1002/cne.902410203

118. Evans JJ, Anderson GM. Balancing ovulation and anovulation: integration of the reproductive and energy balance axes by neuropeptides. Hum Reprod Update (2012) 18(3):313-32. doi:10.1093/ humupd/dms004

119. Raposinho PD, Pierroz DD, Broqua P, White RB, Pedrazzini T, Aubert ML. Chronic administration of neuropeptide $\mathrm{Y}$ into the lateral ventricle of C57BL/6] male mice produces an obesity syndrome including hyperphagia, hyperleptinemia, insulin resistance, and hypogonadism. Mo Cell Endocrinol (2001) 185(12):195-204. doi:10.1016/S03037207(01)00620-7

120. Pierroz DD, Gruaz NM, d'Alieves V, Aubert ML. Chronic administration of neuropeptide $\mathrm{Y}$ into the lateral ventricle starting at 30 days of life delays sexual maturation in the female rat. Neuroendocrinology (1995) 61(3):293-300. doi:10.1159/000126851

121. Catzeflis C, Pierroz DD, RohnerJeanrenaud F, Rivier JE, Sizonenko PC, Aubert ML. Neuropeptide $\mathrm{Y}$ administered chronically into the lateral ventricle profoundly inhibits both the gonadotropic and the somatotropic axis in intact adult female rats. Endocrinology (1993) 132(1):224-34. doi:10. 1210/en.132.1.224

122. Kerkerian L, Guy J, Lefevre G, Pelletier G. Effects of neuropeptide $Y$ (NPY) on the release of anterior pituitary hormones in the rat. Peptides (1985) 6(6):1201-4. doi:10. 1016/0196-9781(85)90451-6

123. Kaynard AH, Pau KY, Hess DL, Spies HG. Third-ventricular infusion of neuropeptide $\mathrm{Y}$ suppresses luteinizing hormone secretion in ovariectomized rhesus macaques. Endocrinology (1990) 127(5):2437-44. doi:10.1210/endo-127-5-2437

124. Sahu A, Crowley WR, Tatemoto K, Balasubramaniam A, Kalra SP. Effects of neuropeptide Y, NPY analog (norleucine4$\mathrm{NPY}$ ), galanin and neuropeptide $\mathrm{K}$ on $\mathrm{LH}$ release in ovariectomized (ovx) and ovx estrogen, progesterone-treated rats. Peptides (1987) 8(5):921-6. doi:10.1016/ 0196-9781(87)90081-7

125. Pennefather JN, Lecci A, Candenas ML, Patak E, Pinto FM, Maggi CA. Tachykinins and tachykinin receptors: a growing family. Life Sci (2004) 74(12):1445-63. doi:10. 1016/j.lfs.2003.09.039

126. Lasaga M, Debeljuk L. Tachykinins and the hypothalamo-pituitarygonadal axis: an update. Peptides (2011) 32(9):1972-8. doi:10.1016/ j.peptides.2011.07.009

127. Wormald PJ, Millar RP, Kerdelhue B. Substance $\mathrm{P}$ receptors in human pituitary: a potential inhibitor of luteinizing hormone secretion. J Clin Endocrinol Metab (1989) 69(3):612-5. doi:10.1210/ jcem-69-3-612

128. Arisawa M, De Palatis L, Ho R, Snyder GD, Yu WH, Pan G, et al. Stimulatory role of substance $P$ on gonadotropin release in ovariectomized rats. Neuroendocrinology (1990) 51(5):523-9. doi:10.1159/ 000125386

129. Tsuruo Y, Hisano S, Okamura Y, Tsukamoto N, Daikoku S. Hypothalamic substance P-containing neurons. Sex-dependent topographical differences and ultrastructural transformations associated with stages of the estrous cycle. Brain Res (1984) 305(2):331-41. doi:10.1016/00068993(84)90439-6

130. Tsuruo Y, Hisano S, Nakanishi J, Katoh S, Daikoku S. Immunohistochemical studies on the roles of substance $\mathrm{P}$ in the rat hypothalamus: possible implication in the hypothalamic-hypophysialgonadal axis. Neuroendocrinology (1987) 45(5):389-401. doi:10. 1159/000124764

131. Tsuruo Y, Kawano H, Hisano S, Kagotani Y, Daikoku S, Zhang $\mathrm{T}$, et al. Substance P-containing neurons innervating LHRHcontaining neurons in the septopreoptic area of rats. Neuroendocrinology (1991) 53(3):236-45. doi:10.1159/000125724

132. Hokfelt T, Pernow B, Nilsson G, Wetterberg L, Goldstein M, 
Jeffcoate SL. Dense plexus of substance $\mathrm{P}$ immunoreactive nerve terminals in eminentia medialis of the primate hypothalamus. Proc Natl Acad Sci U S A (1978) 75(2):1013-5. doi:10.1073/ pnas.75.2.1013

133. Burke MC, Letts PA, Krajewski SJ, Rance NE. Coexpression of dynorphin and neurokinin B immunoreactivity in the rat hypothalamus: morphologic evidence of interrelated function within the arcuate nucleus. J Comp Neurol (2006) 498(5):712-26. doi:10.1002/cne.21086

134. Gottsch ML, Popa SM, Lawhorn JK, Qiu J, Tonsfeldt KJ, Bosch MA, et al. Molecular properties of Kiss1 neurons in the arcuate nucleus of the mouse. Endocrinology (2011) 152(11):4298-309. doi: 10.1210/en.2011-1521

135. Tatemoto K, Rokaeus A, Jornvall H, McDonald TJ, Mutt V. Galanin a novel biologically active peptide from porcine intestine. FEBS Lett (1983) 164(1):124-8. doi:10.1016/ 0014-5793(83)80033-7

136. Hokfelt T, Tatemoto K. Galanin: a multitalented neuropeptide. EXS (2010) 102:1-5.

137. Kaplan LM, Gabriel SM, Koenig JI, Sunday ME, Spindel ER, Martin JB, et al. Galanin is an estrogen-inducible, secretory product of the rat anterior pituitary. Proc Natl Acad Sci U S A (1988) 85(19):7408-12. doi:10. 1073/pnas.85.19.7408

138. Lopez FJ, Merchenthaler I, Ching M, Wisniewski MG, Negro-Vilar A. Galanin: a hypothalamichypophysiotropic hormone modulating reproductive functions. Proc Natl Acad Sci U $S$ A (1991) 88(10):4508-12. doi:10.1073/pnas.88.10.4508

139. Sahu A, Xu B, Kalra SP. Role of galanin in stimulation of pituitary luteinizing hormone secretion as revealed by a specific receptor antagonist, galantide. Endocrinology (1994) 134(2):529-36. doi:10. 1210/en.134.2.529

140. Merchenthaler I. The hypophysiotropic galanin system of the rat brain. Neuroscience (1991) 44(3):643-54. doi:10.1016/03064522(91)90084-2

141. Merchenthaler I, Lopez FJ, Lennard DE, Negro-Vilar A. Sexual differences in the distribution of neurons coexpressing galanin and luteinizing hormone-releasing hormone in the rat brain. Endocrinology
(1991) 129(4):1977-86. doi:10.1210/endo-129-4-1977

142. Rajendren G, Li X. Galanin synaptic input to gonadotropinreleasing hormone perikarya in juvenile and adult female mice: implications for sexual maturity. Brain Res Dev Brain Res (2001) 131(1-2):161-5. doi:10. 1016/S0165-3806(01)00257-7

143. Li XF, Knox AM, O’Byrne KT. Corticotrophin-releasing factor and stress-induced inhibition of the gonadotrophin-releasing hormone pulse generator in the female. Brain Res (2010) 1364:153-63. doi:10.1016/j. brainres.2010.08.036

144. Williams CL, Nishihara M, Thalabard JC, Grosser PM, Hotchkiss J, Knobil E. Corticotropin-releasing factor and gonadotropin-releasing hormone pulse generator activity in the rhesus monkey. Electrophysiological studies. Neuroendocrinology (1990) 52(2):133-7. doi:10. $1159 / 000125563$

145. Cates PS, Li XF, O’Byrne KT. The influence of 17beta-oestradiol on corticotrophin-releasing hormone induced suppression of luteinising hormone pulses and the role of CRH in hypoglycaemic stressinduced suppression of pulsatile LH secretion in the female rat. Stress (2004) 7(2):113-8. doi:10. 1080/1025389042000218988

146. MacLusky NJ, Naftolin F, Leranth C. Immunocytochemical evidence for direct synaptic connections between corticotrophin-releasing factor (CRF) and gonadotrophinreleasing hormone (GnRH)containing neurons in the preoptic area of the rat. Brain Res (1988) 439(1-2):391-5. doi:10.1016/ 0006-8993(88)91501-6

147. Dudas B, Merchenthaler I. Close juxtapositions between luteinizing hormone-releasing hormone-immunoreactive neurons and corticotropinreleasing factor-immunoreactive axons in the human diencephalon. $J$ Clin Endocrinol Metab (2002) 87(12):5778-84. doi:10.1210/jc.2002-020996

148. Topaloglu AK, Tello JA, Kotan LD, Ozbek MN, Yilmaz MB, Erdogan S, et al. Inactivating KISS1 mutation and hypogonadotropic hypogonadism. $N$ Engl J Med (2012) 366(7):629-35. doi: 10.1056/NEJMoa1111184

149. Seminara SB, Messager S, Chatzidaki EE, Thresher RR, Acierno JS Jr, Shagoury JK, et al. The GPR54 gene as a regulator of puberty. $N$ Engl $J$ Med (2003) 349(17):1614-27. doi:10.1056/NEJMoa035322

150. de Roux N, Genin E, Carel JC, Matsuda F, Chaussain JL, Milgrom E. Hypogonadotropic hypogonadism due to loss of function of the KiSS1-derived peptide receptor GPR54. Proc Natl Acad Sci U S A (2003) 100(19):10972-6. doi:10. 1073/pnas. 1834399100

151. Kinoshita M, Tsukamura H, Adachi S, Matsui H, Uenoyama $\mathrm{Y}$, Iwata $\mathrm{K}$, et al. Involvement of central metastin in the regulation of preovulatory luteinizing hormone surge and estrous cyclicity in female rats. Endocrinology (2005) 146(10):4431-6. doi:10.1210/en.2005-0195

152. Clarkson J, Boon WC, Simpson ER, Herbison AE. Postnatal development of an estradiolkisspeptin positive feedback mechanism implicated in puberty onset. Endocrinology (2009) 150(7):3214-20. doi:10.1210/en.2008-1733

153. Messager S, Chatzidaki EE, Ma D, Hendrick AG, Zahn D, Dixon J, et al. Kisspeptin directly stimulates gonadotropin-releasing hormone release via $G$ protein-coupled receptor 54. Proc Natl Acad Sci U $S$ A (2005) 102(5):1761-6. doi:10. 1073/pnas.0409330102

154. Irwig MS, Fraley GS, Smith JT, Acohido BV, Popa SM, Cunningham MJ, et al. Kisspeptin activation of gonadotropin releasing hormone neurons and regulation of KiSS-1 mRNA in the male rat. Neuroendocrinology (2004) 80(4):264-72. doi: $10.1159 / 000083140$

155. Han SK, Gottsch ML, Lee KJ, Popa SM, Smith JT, Jakawich SK, et al. Activation of gonadotropinreleasing hormone neurons by kisspeptin as a neuroendocrine switch for the onset of puberty. Neurosci (2005) 25(49):11349-56. doi:10.1523/JNEUROSCI.332805.2005

156. Dumalska I, Wu M, Morozova E, Liu R, van den Pol A, Alreja M. Excitatory effects of the pubertyinitiating peptide kisspeptin and group I metabotropic glutamate receptor agonists differentiate two distinct subpopulations of gonadotropin-releasing hormone neurons. J Neurosci (2008) 28(32):8003-13. doi:10.1523/ JNEUROSCI.1225-08.2008

157. Pielecka-Fortuna J, Chu Z, Moenter SM. Kisspeptin acts directly and indirectly to increase gonadotropin-releasing hormone neuron activity and its effects are modulated by estradiol. Endocrinology (2008) 149(4):1979-86. doi:10.1210/en.2007-1365

158. Kauffman AS, Gottsch ML, Roa J, Byquist AC, Crown A, Clifton DK, et al. Sexual differentiation of Kiss1 gene expression in the brain of the rat. Endocrinology (2007) 148(4):1774-83. doi: 10.1210/en.2006-1540

159. Adachi S, Yamada S, Takatsu Y, Matsui H, Kinoshita M, Takase $\mathrm{K}$, et al. Involvement of anteroventral periventricular metastin/kisspeptin neurons in estrogen positive feedback action on luteinizing hormone release in female rats. $J$ Reprod Dev (2007) 53(2):367-78. doi:10.1262/jrd.18146

160. Herbison AE. Estrogen positive feedback to gonadotropinreleasing hormone (GnRH) neurons in the rodent: the case for the rostral periventricular area of the third ventricle (RP3V). Brain Res Rev (2008) 57(2):277-87. doi:10 1016/j.brainresrev.2007.05.006

161. Clarkson J, d'Anglemont de Tassigny X, Moreno AS, Colledge WH, Herbison AE. Kisspeptin-GPR54 signaling is essential for preovulatory gonadotropin-releasing hormone neuron activation and the luteinizing hormone surge. $\mathrm{J} \mathrm{Neu-}$ rosci (2008) 28(35):8691-7. doi:10. 1523/JNEUROSCI.1775-08.2008

162. Hoffman GE, Le WW, Franceschini I, Caraty A, Advis JP. Expression of fos and in vivo median eminence release of LHRH identifies an active role for preoptic area kisspeptin neurons in synchronized surges of LH and LHRH in the ewe. Endocrinology (2011) 152(1):214-22. doi:10. 1210/en.2010-0066

163. Merkley CM, Porter KL, Coolen LM, Hileman SM, Billings $\mathrm{HJ}$, Drews S, et al. KNDy (kisspeptin/neurokinin $\mathrm{B} /$ dynorphin) neurons are activated during both pulsatile and surge secretion of LH in the ewe. Endocrinology (2012) 153(11):5406-14. doi:10.1210/en.2012-1357

164. Goodman RL, Lehman MN, Smith JT, Coolen LM, de Oliveira $\mathrm{CV}$, Jafarzadehshirazi MR, et al. Kisspeptin neurons in the arcuate nucleus of the ewe express both dynorphin $\mathrm{A}$ and neurokinin B. Endocrinology (2007) 148(12):5752-60. doi:10.1210/en. 2007-0961 
165. Smith JT, Dungan HM, Stoll EA, Gottsch ML, Braun RE, Eacker $\mathrm{SM}$, et al. Differential regulation of KiSS-1 mRNA expression by sex steroids in the brain of the male mouse. Endocrinology (2005) 146(7):2976-84. doi: 10.1210/en.2005-0323

166. Smith JT, Clay CM, Caraty A, Clarke IJ. KiSS-1 messenger ribonucleic acid expression in the hypothalamus of the ewe is regulated by sex steroids and season. Endocrinology (2007) 148(3):1150-7. doi:10.1210/en.2006-1435

167. Smith JT, Li Q, Pereira A, Clarke IJ. Kisspeptin neurons in the ovine arcuate nucleus and preoptic area are involved in the preovulatory luteinizing hormone surge. Endocrinology (2009) 150(12):5530-8. doi:10.1210/en. 2009-0712

168. Cheng G, Coolen LM, Padmanabhan V, Goodman RL, Lehman MN. The kisspeptin/neurokinin $\mathrm{B} /$ dynorphin (KNDy) cell population of the arcuate nucleus: sex differences and effects of prenatal testosterone in sheep. Endocrinology (2010) 151(1):301-11. doi:10. 1210/en.2009-0541

169. Lehman MN, Coolen LM, Goodman RL. Minireview: kisspeptin/neurokinin B/dynorphin (KNDy) cells of the arcuate nucleus: a central node in the control of gonadotropin-releasing hormone secretion. Endocrinology (2010) 151(8):3479-89. doi:10.1210/en.2010-0022

170. Ramaswamy S, Seminara SB, Ali B, Ciofi P, Amin NA, Plant TM. Neurokinin B stimulates GnRH release in the male monkey (Macaca mulatta) and is colocalized with kisspeptin in the arcuate nucleus. Endocrinology (2010) 151(9):4494-503. doi:10.1210/en. 2010-0223

171. Topaloglu AK, Reimann F, Guclu M, Yalin AS, Kotan LD, Porter KM, et al. TAC3 and TACR3 mutations in familial hypogonadotropic hypogonadism reveal a key role for Neurokinin B in the central control of reproduction. Nat Genet (2009) 41(3):354-8. doi:10.1038/ ng.306

172. Guran T, Tolhurst G, Bereket A, Rocha N, Porter K, Turan S, et al. Hypogonadotropic hypogonadism due to a novel missense mutation in the first extracellular loop of the neurokinin B receptor. J Clin Endocrinol
Metab (2009) 94(10):3633-9. doi: 10.1210/jc.2009-0551

173. Amstalden M, Coolen LM, Hemmerle AM, Billings HJ, Connors JM, Goodman RL, et al. Neurokinin 3 receptor immunoreactivity in the septal region, preoptic area and hypothalamus of the female sheep: colocalisation in neurokinin B cells of the arcuate nucleus but not in gonadotrophin-releasing hormone neurones. J Neuroendocrinol (2010) 22(1):1-12. doi: $10.1111 / \mathrm{j}$. 1365-2826.2009.01930.x

174. Navarro VM, Gottsch ML, Wu M, Garcia-Galiano D, Hobbs SJ, Bosch MA, et al. Regulation of NKB pathways and their roles in the control of Kiss1 neurons in the arcuate nucleus of the male mouse. Endocrinology (2011) 152(11):4265-75. doi:10.1210/en. 2011-1143

175. Blank MS, Roberts DL. Antagonist of gonadotropin-releasing hormone blocks naloxoneinduced elevations in serum luteinizing hormone. Neuroendocrinology (1982) 35(5):309-12. doi:10.1159/000123399

176. Wiesner JB, Koenig JI, Krulich L, Moss RL. Site of action for beta-endorphin-induced changes in plasma luteinizing hormone and prolactin in the ovariectomized rat. Life Sci (1984) 34(15):1463-73. doi:10.1016/ 0024-3205(84)90061-4

177. Schulz R, Wilhelm A, Pirke KM, Gramsch C, Herz A. Betaendorphin and dynorphin control serum luteinizing hormone level in immature female rats. Nature (1981) 294(5843):757-9. doi:10. 1038/294757a0

178. Dudas B, Merchenthaler I. Close anatomical associations between beta-endorphin and luteinizing hormone-releasing hormone neuronal systems in the human diencephalon. Neuroscience (2004) 124(1):221-9. doi:10.1016/ j.neuroscience.2003.11.021

179. Dudas B, Merchenthaler I. Catecholaminergic axons innervate LH-releasing hormone immunoreactive neurons of the human diencephalon. $J$ Clin Endocrinol Metab (2001) 86(11):5620-6. doi:10.1210/jc.86.11.5620

180. Dudas B, Merchenthaler I. Topography and associations of leu-enkephalin and luteinizing hormone-releasing hormone neuronal systems in the human diencephalon. J Clin Endocrinol
Metab (2003) 88(4):1842-8. doi:10.1210/jc.2002-021416

181. May PB, Mittler JC, Ertel NH. Enkephalins and pituitary hormone release: modification of responsiveness to LHRH. Horm Res (1979) 10(2-3):57-63. doi:10. 1159/000178989

182. Porteous R, Petersen SL, Yeo SH, Bhattarai JP, Ciofi P, de Tassigny $\mathrm{XD}$, et al. Kisspeptin neurons co-express met-enkephalin and galanin in the rostral periventricular region of the female mouse hypothalamus. I Comp Neurol (2011) 519(17):3456-69. doi:10. 1002/cne.22716

183. Dahl SK, Amstalden M, Coolen L, Fitzgerald M, Lehman M. Dynorphin immunoreactive fibers contact GnRH neurons in the human hypothalamus. Reprod Sci (2009) 16(8):781-7. doi:10.1177/ 1933719109336619

184. Tsutsui K, Saigoh E, Ukena $\mathrm{K}$, Teranishi $\mathrm{H}$, Fujisawa $\mathrm{Y}$, Kikuchi M, et al. A novel avian hypothalamic peptide inhibiting gonadotropin release. Biochem Biophys Res Commun (2000) 275(2):661-7. doi:10.1006/bbrc.2000.3350

185. Bentley GE, Perfito N, Ukena $\mathrm{K}$, Tsutsui K, Wingfield JC. Gonadotropin-inhibitory peptide in song sparrows (Melospiza melodia) in different reproductive conditions, and in house sparrows (Passer domesticus) relative to chicken-gonadotropin-releasing hormone. $J$ Neuroendocrinol (2003) 15(8):794-802. doi:10 1046/j.1365-2826.2003.01062.x

186. Ubuka T, Kim S, Huang YC, Reid J, Jiang J, Osugi $T$, et al. Gonadotropin-inhibitory hormone neurons interact directly with gonadotropinreleasing hormone-I and -II neurons in European starling brain. Endocrinology (2008) 149(1):268-78. doi:10.1210/en.2007-0983

187. Hinuma S, Shintani Y, Fukusumi S, Iijima N, Matsumoto $\mathrm{Y}$, Hosoya $\mathrm{M}$, et al. New neuropeptides containing carboxy-terminal RFamide and their receptor in mammals. Nat Cell Biol (2000) 2(10):703-8. doi:10.1038/35036326

188. Yano T, Iijima N, Kakihara $\mathrm{K}$, Hinuma S, Tanaka M, Ibata Y. Localization and neuronal response of RFamide related peptides in the rat central nervous system. Brain Res (2003) 982(2):156-67. doi:10.1016/ S0006-8993(03)02877-4
189. Yano T, Iijima $N$, Hinuma $S$, Tanaka M, Ibata Y. Developmental expression of RFamide-related peptides in the rat central nervous system. Brain Res Dev Brain Res (2004) 152(2):109-20. doi:10. 1016/j.devbrainres.2004.06.008

190. Kriegsfeld LJ, Mei DF, Bentley GE, Ubuka T, Mason AO, Inoue K, et al. Identification and characterization of a gonadotropin-inhibitory system in the brains of mammals Proc Natl Acad Sci U S A (2006) 103(7):2410-5. doi:10.1073/pnas. 0511003103

191. Bentley GE, Kriegsfeld LJ, Osugi T, Ukena K, O'Brien S, Perfito N, et al. Interactions of gonadotropinreleasing hormone (GnRH) and gonadotropin-inhibitory hormone $(\mathrm{GnIH})$ in birds and mammals. J Exp Zool A Comp Exp Biol (2006) 305(9):807-14. doi:10.1002/jez.a.306

192. Rizwan MZ, Porteous R, Herbison $\mathrm{AE}$, Anderson GM. Cells expressing RFamiderelated peptide-1/3, the mammalian gonadotropin-inhibitory hormone orthologs, are not hypophysiotropic neuroendocrine neurons in the rat. Endocrinology (2009) 150(3):1413-20. doi:10.1210/en.2008-1287

193. Smith JT, Coolen LM, Kriegsfeld LJ, Sari IP, Jaafarzadehshirazi MR, Maltby $M$, et al. Variation in kisspeptin and RFamiderelated peptide (RFRP) expression and terminal connections to gonadotropin-releasing hormone neurons in the brain: a novel medium for seasonal breeding in the sheep. Endocrinology (2008) 149(11):5770-82. doi:10.1210/en. 2008-0581

194. Wu M, Dumalska I, Morozova E, van den Pol A, Alreja M. Melanin-concentrating hormone directly inhibits GnRH neurons and blocks kisspeptin activation, linking energy balance to reproduction. Proc Natl Acad Sci U S A (2009) 106(40):17217-22. doi:10. 1073/pnas.0908200106

195. Johnson MA, Tsutsui K, Fraley GS. Rat RFamide-related peptide3 stimulates GH secretion, inhibits LH secretion, and has variable effects on sex behavior in the adult male rat. Horm Behav (2007) 51(1):171-80. doi:10.1016/ j.yhbeh.2006.09.009

196. Clarke IJ, Sari IP, Qi Y, Smith JT, Parkington HC, Ubuka T, et al. Potent action of RFamiderelated peptide- 3 on pituitary gonadotropes indicative of a 
hypophysiotropic role in the negative regulation of gonadotropin secretion. Endocrinology (2008) 149(11):5811-21. doi:10.1210/en. 2008-0575

197. Murakami M, Matsuzaki T, Iwasa $\mathrm{T}$, Yasui $\mathrm{T}$, Irahara $\mathrm{M}$, Osugi $\mathrm{T}$, et al. Hypophysiotropic role of RFamide-related peptide- 3 in the inhibition of $\mathrm{LH}$ secretion in female rats. J Endocrinol (2008) 199(1):105-12. doi:10.1677/JOE08-0197

198. Kadokawa H, Shibata M, Tanaka Y, Kojima T, Matsumoto K, Oshima $\mathrm{K}$, et al. Bovine C-terminal octapeptide of RFamide-related peptide-3 suppresses luteinizing hormone (LH) secretion from the pituitary as well as pulsatile LH secretion in bovines. Domest Anim Endocrinol (2009) 36(4):219-24. doi:10.1016/j.domaniend.2009.02. 001

199. Ukena K, Tsutsui K. Distribution of novel RFamide-related peptide-like immunoreactivity in the mouse central nervous system. Neurosci Lett (2001) 300(3):153-6. doi:10.1016/S03043940(01)01583-X

200. Ubuka T, Lai H, Kitani M, Suzuuchi A, Pham V, Cadigan $\mathrm{PA}$, et al. Gonadotropin-inhibitory hormone identification, cDNA cloning, and distribution in rhesus macaque brain. J Comp Neurol (2009) 517(6):841-55. doi:10. 1002/cne.22191

201. Gaskins GT, Moenter SM. Orexin a suppresses gonadotropin-releasing hormone $(\mathrm{GnRH})$ neuron activity in the mouse. Endocrinology (2012) 153(8):3850-60. doi:10.1210/en.2012-1300

202. Iqbal J, Pompolo S, Sakurai T, Clarke IJ. Evidence that orexincontaining neurones provide direct input to gonadotropinreleasing hormone neurones in the ovine hypothalamus. J Neuroendocrinol (2001) 13(12):1033-41. doi:10.1046/j.1365-2826.2001. 00719.x

203. Leslie RA, Sanders SJ, Anderson SI, Schuhler S, Horan TL, Ebling FJ. Appositions between cocaine and amphetamine-related transcriptand gonadotropin releasing hormone-immunoreactive neurons in the hypothalamus of the Siberian hamster. Neurosci Lett (2001) 314(3):111-4. doi:10.1016/ S0304-3940(01)02291-1

204. Havern RL, Whisnant CS, Goodman RL. Hypothalamic sites of catecholamine inhibition of luteinizing hormone in the anestrous ewe. Biol Reprod (1991) 44(3):476-82. doi:10.1095/biolreprod44.3.476

205. Drouva SV, Gallo RV. Catecholamine involvement in episodic luteinizing hormone release in adult ovariectomized rats. Endocrinology (1976) 99(3):651-8. doi:10.1210/endo-99-3-651

206. Le WW, Berghorn KA, Smith MS, Hoffman GE. Alphal-adrenergic receptor blockade blocks LH secretion but not LHRH cFos activation. Brain Res (1997) 747(2):236-45. doi:10.1016/ S0006-8993(96)01269-3

207. Adler BA, Johnson MD, Lynch CO, Crowley WR. Evidence that norepinephrine and epinephrine systems mediate the stimulatory effects of ovarian hormones on luteinizing hormone and luteinizing hormone-releasing hormone. Endocrinology (1983) 113(4):1431-8. doi:10.1210/endo113-4-1431

208. Li PH. Catecholamine inhibition of luteinizing hormone secretion in isolated pig pituitary cells. Biol Reprod (1989) 40(5):914-9. doi: 10.1095/biolreprod40.5.914

209. Hoffman GE. Organization of LHRH cells: differential apposition of neurotensin, substance $\mathrm{P}$ and catecholamine axons. Peptides (1985) 6(3):439-61. doi:10.1016/ 0196-9781(85)90110-X

210. Panula P, Pirvola U, Auvinen S, Airaksinen MS. Histamineimmunoreactive nerve fibers in the rat brain. Neuroscience (1989) 28(3):585-610. doi:10.1016/03064522(89)90007-9

211. Sawyer CH. Rhinencephalic involvement in pituitary activation by intraventricular histamine in the rabbit under nembutal anesthesia. Am J Physiol (1955) 180(1):37-46.

212. Noris G, Hol D, Clapp C, Martinez de la Escalera G. Histamine directly stimulates gonadotropin-releasing hormone secretion from GT1-1 cells via H1 receptors coupled to phosphoinositide hydrolysis. Endocrinology (1995) 136(7):2967-74. doi:10.1210/en.136.7.2967

213. Ishunina $T A$, van Heerikhuize JJ, Ravid R, Swaab DF. Estrogen receptors and metabolic activity in the human tuberomamillary nucleus: changes in relation to sex, aging and Alzheimer's disease. Brain Res (2003) 988(1-2):84-96. doi:10.1016/S0006-8993(03) 03347-X
214. Decavel C, Van den Pol AN. GABA: a dominant neurotransmitter in the hypothalamus. J Comp Neurol (1990) 302(4):1019-37. doi:10. 1002/cne.903020423

215. van den Pol AN, Wuarin JP, Dudek FE. Glutamate, the dominant excitatory transmitter in neuroendocrine regulation. Science (1990) 250(4985):1276-8. doi:10. 1126/science.1978759

216. Christian CA, Moenter SM. The neurobiology of preovulatory and estradiol-induced gonadotropinreleasing hormone surges. Endocr Rev (2010) 31(4):544-77. doi:10 1210/er.2009-0023

217. Leranth C, MacLusky NJ Sakamoto H, Shanabrough M, Naftolin F. Glutamic acid decarboxylase-containing axons synapse on LHRH neurons in the rat medial preoptic area. Neuroendocrinology (1985) 40(6):536-9. doi:10.1159/000124127

218. Spergel DJ, Kruth U, Hanley DF, Sprengel R, Seeburg PH. GABA- and glutamate-activated channels in green fluorescent protein-tagged gonadotropinreleasing hormone neurons in transgenic mice. J Neurosci (1999) 19(6):2037-50.

219. DeFazio RA, Heger S, Ojeda SR, Moenter SM. Activation of A-type gammaaminobutyric acid receptors excites gonadotropin-releasing hormone neurons. Mol Endocrinol (2002) 16(12):2872-91. doi:10.1210/me.2002-0163

220. Sullivan SD, DeFazio RA, Moenter SM. Metabolic regulation of fertility through presynaptic and postsynaptic signaling to gonadotropin-releasing hormone neurons. J Neurosci (2003) 23(24):8578-85.

221. Lagrange $\mathrm{AH}$, Ronnekleiv $\mathrm{OK}$ Kelly MJ. Estradiol-17 beta and mu-opioid peptides rapidly hyperpolarize GnRH neurons: a cellular mechanism of negative feedback? Endocrinology (1995) 136(5):2341-4 doi:10.1210/en.136.5.2341

222. Han SK, Abraham IM, Herbison AE. Effect of GABA on GnRH neurons switches from depolarization to hyperpolarization at puberty in the female mouse. Endocrinology (2002) 143(4):1459-66. doi: 10.1210/en.143.4.1459

223. Herbison AE, Moenter SM. Depolarising and hyperpolarising actions of GABA(A) receptor activation on gonadotrophinreleasing hormone neurones: towards an emerging consensus. J Neuroendocrinol (2011) 23(7):557-69. doi:10.1111/j.13652826.2011.02145.x

224. Watanabe M, Sakuma Y, Kato M. GABAA receptors mediate excitation in adult rat $\mathrm{GnRH}$ neurons. Biol Reprod (2009) 81(2):327-32. doi:10.1095/biolreprod.108. 074583

225. Farkas I, Kallo I, Deli L, Vida B, Hrabovszky E, Fekete C, et al. Retrograde endocannabinoid signaling reduces GABAergic synaptic transmission to gonadotropin-releasing hormone neurons. Endocrinology (2010) 151(12):5818-29. doi:10.1210/en.2010-0638

226. Goldsmith PC, Thind KK, Perera AD, Plant TM. Glutamateimmunoreactive neurons and their gonadotropin-releasing hormoneneuronal interactions in the monkey hypothalamus. Endocrinology (1994) 134(2):858-68. doi:10. 1210/en.134.2.858

227. Kiss J, Kocsis K, Csaki A, Halasz B. Evidence for vesicular glutamate transporter synapses onto gonadotropin-releasing hormone and other neurons in the rat medial preoptic area. Eur J Neurosci (2003) 18(12):3267-78. doi:10.1111/j.1460-9568.2003. 03085. $\mathrm{x}$

228. Taziaux M, Swaab DF, Bakker J. Sex differences in the neurokinin $B$ system in the human infundibular nucleus. J Clin Endocrinol Metab (2012) 97(12):E2210-20. doi:10. 1210/jc.2012-1554

229. Araujo AB, Wittert GA. Endocrinology of the aging male. Best Pract Res Clin Endocrinol Metab (2011) 25(2):303-19. doi:10.1016/j.beem.2010.11.004

230. Veldhuis JD, Takahashi PY, Keenan DM, Liu PY, Mielke KL, Weist SM. Age disrupts androgen receptormodulated negative feedback in the gonadal axis in healthy men. Am J Physiol Endocrinol Metab (2010) 299(4):E675-82. doi:10. 1152/ajpendo.00300.2010

231. Wu FC, Tajar A, Beynon JM, Pye SR, Silman AJ, Finn JD, et al. Identification of lateonset hypogonadism in middleaged and elderly men. $N$ Engl $J$ Med (2010) 363(2):123-35. doi:10. 1056/NEJMoa0911101

232. Rance NE, Uswandi SV, McMullen NT. Neuronal hypertrophy in the hypothalamus of older men. Neurobiol Aging (1993) 14(4):337-42. doi:10.1016/01974580(93)90119-V 
233. Witkin JW. Aging changes in synaptology of luteinizing hormone-releasing hormone neurons in male rat preoptic area. Neuroscience (1987) 22(3):1003-13. doi:10.1016/03064522(87)92976-9

Conflict of Interest Statement: The authors declare that the research was conducted in the absence of any commercial or financial relationships that could be construed as a potential conflict of interest.

Received: 18 July 2013; paper pending published: 06 August 2013; accepted: 03 September 2013; published online: 20 September 2013.
Citation: Hrabovszky $E$ and Liposits $Z$ (2013) Afferent neuronal control of type-I gonadotropin releasing hormone neurons in the human. Front. Endocrinol. 4:130. doi: 10.3389/fendo.2013.00130

This article was submitted to Experimental Endocrinology, a section of the journal Frontiers in Endocrinology.

Copyright (C) 2013 Hrabovszky and

Liposits. This is an open-access article distributed under the terms of the Creative Commons Attribution License (CC $B Y)$. The use, distribution or reproduction in other forums is permitted, provided the original author(s) or licensor are credited and that the original publication in this journal is cited, in accordance with accepted academic practice. No use, distribution or reproduction is permitted which does not comply with these terms. 